\title{
Evaporation Research: Review and Interpretation
}

\author{
C. M. Burt ${ }^{1}$; A. J. Mutziger ${ }^{2}$; R. G. Allen ${ }^{3}$; and T. A. Howell ${ }^{4}$
}

Abstract: Literature regarding evaporation from soil, wet plant surfaces, and sprinkler droplets was examined, normalized, and interpreted. Much of the evaporation literature is difficult to compare and interpret; this paper offers comparisons and discussions of various findings by others as well as by the writers. Techniques of measuring and estimating evaporation from irrigation and rainfall are discussed. The partitioning between increased evaporation and decreased transpiration from a variety of research is quantified. Factors that impact the various forms of evaporation are listed and quantified. This review and summary will provide practitioners and researchers with theoretical and practical guidance on measurement techniques and estimates of evaporation under a wide range of conditions.

CE Database subject headings: Evaporation; Evapotranspiration; Lysimeters; Irrigation scheduling; Soil water; Transpiration.

\section{Background}

Evapotranspiration (ET) represents the major consumptive use of irrigation water and rainfall on agricultural land. There has been considerable research to define ET for various crops and to understand the relationship between ET and crop yield. Because transpiration $(T)$ is the portion of ET that flows through the plant system, it is the main component of ET that impacts the ET yield relationship. Nevertheless, the evaporation $(E)$ component within and outside the crop growing season can be a significant component of the total ET. Given the increased competition for water, it is important to search for new ways to conserve water and/or to use it more efficiently. This paper examines the factors that affect the $E$ component and the relative percentage of $E$ in the overall ET balance.

Most of the literature reviewed provided information in a format that did not lend itself to direct comparison with other literature results. Therefore, within this paper, various data have been rearranged and organized so that results can be compared. However, because of the sheer volume of work required, the writers have not attempted to recreate figures and tables found in the

\footnotetext{
${ }^{1}$ Chairman, Irrigation Training and Research Center (ITRC), BioResource and Agricultural Engineering Department, California Polytechnic State Univ., San Luis Obispo, CA 93407. E-mail: cburt@calpoly.edu

${ }^{2}$ Air Quality Specialist, San Luis Obispo County Air Pollution Control District, San Luis Obispo, CA 93401; formerly, Irrigation Technician II, ITRC, Cal Poly.

${ }^{3}$ Professor of Water Resources Engineering, Univ. of Idaho. Kimberly Research and Extension Center, 3793 N. 3600 E., Kimberly, ID 83341. E-mail: rallen@kimberly.uidaho.edu

${ }^{4}$ Research Leader, USDA-Agricultural Research Service Conservation and Production Research Laboratory. P. O. Drawer 10, Bushland, TX 79012-0010. E-mail: tahowel1@cprl.ars.usda.gov
}

literature; these were simply scanned into the document. It should be noted that the literature reviewed did not consider the influence of shallow groundwater on evaporation, rather, soil evaporation is presented as a natural dry-down phenomena.

\section{What Falls Under Evaporation?}

Evaporation in a soil-plant-atmosphere system occurs from each of the system components. Evaporation from the soil is affected by soil water content, type, and tilth, the presence or absence of surface mulches, and the environmental conditions being imposed on the soil. Evaporation from the plant surfaces is affected by the plant canopy water storage capacity, the length of time that rain or irrigation water is impacting the plants, and the environmental conditions imposed on the plants. Evaporation from the atmosphere (sprinkler droplet evaporation) is associated with sprinkler irrigation methods and is the amount of applied water that does not reach the soil-plant system but does not include drift losses. It is affected by droplet size, relative humidity, angle and distance of droplet travel, and water temperature. Transpiration $(T)$ is a specific form of evaporation in which water from plant tissue is vaporized and removed to the atmosphere primarily through the plant stomata. The combined water that is transferred to the atmosphere through evaporation $(E)$ and transpiration $(T)$ processes is known as evapotranspiration.

\section{Evaporation Equations}

In general, evaporation has been estimated in research using four approaches:

1. Water balance method;

2. Energy balance method;

3. Coupled water and energy balance methods; and

4. Semiempirical and empirical methods.

\section{Water Balance Method}

The general water balance equation for determining evaporative loss from soil, foliage, and sprinkler spray and transpiration is

$$
E+T=P+I+\Delta S-D-R
$$

where $E=$ evaporation; $T=$ transpiration; $P=$ precipitation; $I$ =irrigation; $\Delta S=$ change in soil water storage for the medium of 
interest; and $D$ and $R=$ drainage or runoff losses for the medium of interest. The units are water depth over the evaluated time frame (e.g., mm·day $\left.{ }^{-1}\right)$.

In the soil medium, $E$ can be separated from evapotranspiration by either measuring $E$ with microlysimeters, by measuring $T$ with stem flow gauges, or by having no plants in the system.

\section{Energy Balance Method}

The general surface energy balance equation is given by

$$
L E=\mathrm{ET}=R_{N}-G-H
$$

where $\mathrm{LE}=$ outgoing latent heat flux from evaporation and transpiration; $R_{N}=$ incoming net solar radiation; $G=$ soil heat flux; and $H$ $=$ sensible heat flux above the canopy. The units for these terms are commonly $\mathrm{W} \cdot \mathrm{m}^{-2}\left(1 \mathrm{~mm}\right.$ of ET $\cdot$ day $\left.^{-1}=28.36 \mathrm{~W} \cdot \mathrm{m}^{-2}\right)$. The equation components can be measured remotely with sensing technologies or on the ground with Bowen ratio or Eddy correlation equipment. Considerable work is being done with remote sensing to enable accurate estimation of regional water losses; that work is in the development stages and cannot provide a detailed breakdown of evaporation and transpiration.

A variety of radiation-temperature based energy balance models (Jensen and Haise 1963; Priestley and Taylor 1972; Jensen et al. 1990) have been developed. But over the past 20 years the emphasis has been on the Penman method, modified Penman methods, and the Penman-Monteith methods. These utilize the weather components of solar radiation, relative humidity, wind run, and air temperature to estimate a reference crop ET. When combined with a crop coefficient, the reference crop ET can be used to estimate crop ET. The most recent version of such methods is referred to in this paper as the "FAO-56 Method," which is the procedure described by Allen et al. (1998).

One of the mass transfer models evaluated, Cupid-DPEVAP (Thompson 1993a,b, 1997), determines evaporation from wet foliage with an energy balance equation that uses leaf storage capacity and the depth of the intercepted water. The DPEVAP model and a similar model by Kincaid and Longley (1989) combine heat transfer and diffusion theory in an energy balance to estimate sprinkler evaporation.

\section{Coupled Water and Energy Balance Methods}

Coupled water and energy balance methods tend to be complex and require many field-measured and sensitive parameters, making them impractical for large-scale estimation studies.

\section{Semiempirical and Empirical Methods}

These methods apply only to bare soil evaporation. Several semiempirical and empirical relationships for $E$ have been developed, but they are very site specific (e.g., nontransferable). One such method presented in Stroonsnjider (1987), Gallardo et al. (1996), and Snyder et al. (2000) is a variation on the classic two-stage evaporation model presented by Ritchie (1972). In both methods, Stage 1 evaporation from the soil is limited only by the energy input. For Stage 2, Ritchie (1972) identified a semiempirical evaporation equation that was a function of the square root of time. The more recent papers found a good semiempirical relationship between cumulative bare soil evaporation and cumulative reference evapotranspiration.

\section{Soil Evaporation}

\section{FAO-56 Method and Modifications}

\section{Single and Dual Crop Coefficient in FAO-56}

The Food and Agriculture Organization of the United Nations (FAO) Irrigation and Drainage Paper 56 (Allen et al. 1998) provides a good summary of how crop coefficients in conjunction with reference ET measurements are used to determine ET for the crop $\left(\mathrm{ET}_{c}\right)$ or estimate the partitioning of ET into $E$ and $T$. In general, the single crop coefficient $\left(K_{c}\right)$ is used to define $\mathrm{ET}_{c}$

$$
\mathrm{ET}_{c}=K_{c} \mathrm{ET}_{0}
$$

where $\mathrm{ET}_{0}=\mathrm{ET}$ from a pristine reference grass as defined in FAO-56 (Allen et al. 1998).

The $K_{c}$ term in Eq. (3) can be replaced as a dual crop coefficient to partition $E$ and $T$

$$
K_{c}=K_{s} K_{c b}+K_{e}
$$

where $K_{s}=$ reduction coefficient for crop stress; $K_{c b}=$ basal crop coefficient or the ratio of $\mathrm{ET}_{c}$ to $\mathrm{ET}_{0}$ for dry surface soil conditions in which the water content in the underlying soil does not limit the full plant transpiration needs; and $K_{e}=$ soil water evaporation coefficient. In general, transpiration is obtained by multiplying the product of $K_{s}$ and $K_{c b}$ by $\mathrm{ET}_{0}$, and evaporation is computed by multiplying $K_{e}$ by $\mathrm{ET}_{0}$. Details such as upper limits to the coefficients are discussed by Allen et al. (1998).

\section{Comparison of FAO-56 Kr Against Measured $\mathrm{Kr}$ of Three Soil Types from One Source}

FAO-56 gives the following description of the evaporation reduction coefficient $\mathrm{Kr}$ :

Evaporation from the exposed soil can be assumed to take place in two stages: an energy limiting stage, and a falling rate stage. When the soil surface is wet, $K r$ is 1 . When the water content in the upper soil becomes limiting, $K r$ decreases and becomes zero when the total amount of water that can be evaporated from the topsoil is depleted.

Stage 1 is assumed to exist until the soil surface color lightens due to the loss of moisture. Fig. 1 graphically presents a general case of the two stage relationship. It illustrates Fig. 38 of Allen et al. (1998).

Chanzy and Bruckler (1993) presented the measured $K r$ relationship for three bare soils in Avignon, France (Fig. 2). They used soil samples to compute the volumetric soil water content in the first $0.05 \mathrm{~m}$ of soil and the amount of soil evaporation $(E)$ that was the result of the potential soil evaporation $(E p)$ for a given day as defined by Penman (1948). The evaporation reduction coefficient is then given by $K r=E / E p$.

Because the specific loam, silty clay loam, and clay properties for the Avignon soils presented by Chanzy and Bruckler (1993) were not known, the writers used soil property ranges given in FAO-56 (Table 1) to define average FAO-56 Kr relationship for these soil types (Table 2).

Figs. 3-5 illustrate the $K r$ relationships that were measured (squares and diamonds) by Chanzy and Bruckler (1993) and the average relationships as defined by the writers (ITRC) using FAO-56 (circles and triangles) for the three soil types. The data point in the middle of the ITRC-defined average falling-rate-stage of each $K r$ relationship is the wilting point of the soil.

The key points from this section are 


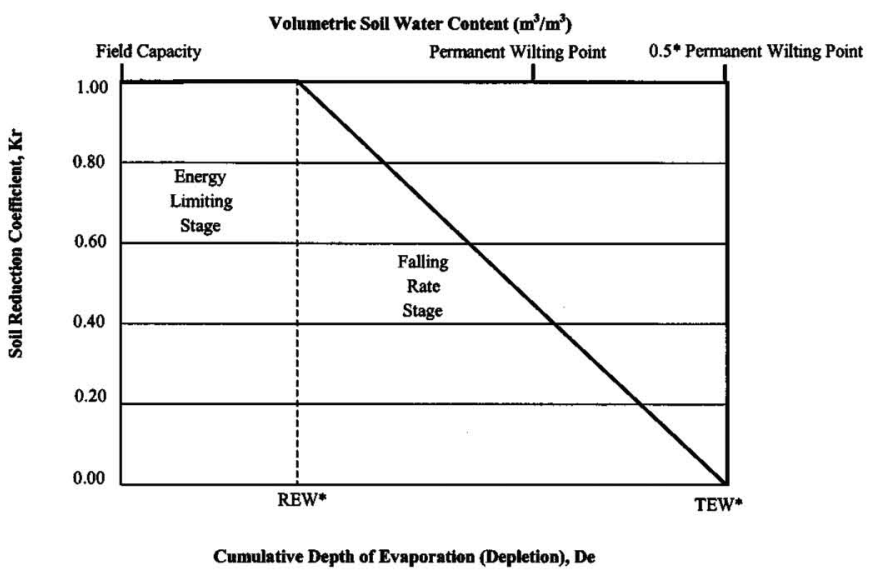

"REW - Readily Evaporable Water *TEW - Total Evaporable Water

Fig. 1. Cumulative evaporation depth (De) or volumetric soil water content versus the FAO-56 soil evaporation reduction coefficient $(\mathrm{Kr})$ (Allen et al. 1998). Note that FAO-56 assumes that the total evaporable water (TEW) has been depleted when the volumetric soil water content is reduced to half of the permanent wilting point water content for the soil.

1. For all three soil types, the measured (Chanzy and Bruckler 1993) $K r$ relationships had nearly identical falling rates.

2. For all three soil types, the average $K r$ relationships from FAO-56 had similar falling rates to the measured rates.

3. The average $K r$ relationships from FAO-56 are shifted relative to the measured $\mathrm{Kr}$ relationships, particularly for the clay. This is an indication that the readily evaporable water (REW) for the Avignon, France soils was somewhat different from the average FAO-56 REW values for that soil.

4. Considering that the FAO-56 computation was done without knowing the soil properties for the three soil types presented by Chanzy and Bruckler (1993), the measured and average $K r$ relationships using FAO-56 are fairly close.

5. "Average" FAO-56 soil textures used to define the $K r$ relationship will give reasonably accurate results.

6. FAO-56 suggests that the depth of the surface soil layer that is subject to evaporation ( $Z e$ ) may be around 0.1 to $0.15 \mathrm{~m}$. Following this, the average $K r$ relationships for the soils were defined by the writers using a $Z e$ of $0.1 \mathrm{~m}$. It is interesting to note that the average $K r$ relationships for the three soils are similar to the measured relationships even though the measured evaporation by Chanzy and Bruckler (1993) was determined by evaluating only the top $0.05 \mathrm{~m}$ of soil.

\section{FAO-56 Modifications}

Allen et al. (1998) presented the FAO Penman-Monteith equation and crop coefficient procedure that computes both the $E$ and $T$ components of crop ET. The soil evaporation computations used the relationship described in the previous section. In a study of evaporation on California's irrigated lands, Burt et al. (2002) made several modifications to the FAO-56 procedure. They were

1. Partitioning the evaporation into precipitation and irrigation origins. Evaporation on the day of a precipitation event and the days following that event were designated as evaporation from precipitation until the available precipitation water was used.

2. The initial basal crop coefficient $\left(K_{c b}\right)$ represents evaporation. Initial $K_{c b}$ values range from $0.15-0.35$. As a plant

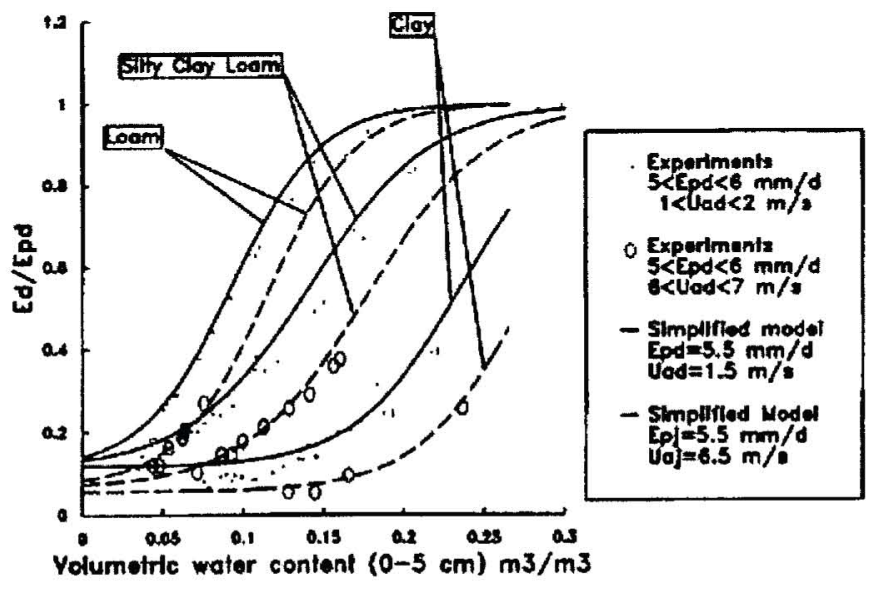

Fig. 2. Ratio of daily bare soil evaporation $(E d)$ to daily potential soil evaporation $(E p d)$ as related to the volumetric water content in the first $5 \mathrm{~cm}$ of soil for three different soil types, one range of Epd, and for two ranges of average daily wind speed ( $(U a d)$. Reprinted with permission from Chanzy and Bruckler (1993) by the American Geophysical Union. (Note: Because higher wind speed results in higher evaporation, it appears that the legend definitions for the dot and circle symbols of this figure (Fig. 8 from Chanzy and Bruckler (1993) need to be interchanged).

emerges or blooms, the evaporation portion of $K_{c b}$ declines. The partitioning procedure between evaporation and transpiration for the initial $K_{c b}$ is described in section B-1.2 of Appendix B by Burt et al. (2002).

3. Evaporation from wet plant surfaces was computed for 2 days per sprinkler application. This is because most sprinklers in California are hand moved sprinklers, which typically wet one area for 2 days. The evaporation for those 2 days was set as the difference in $\mathrm{ET}_{0}$ between a stomatal resistance of $0 \mathrm{~s} / \mathrm{m}$ and $70 \mathrm{~s} / \mathrm{m}$.

4. A third stage of evaporation was included to account for evaporation from open cracks on cracking clay soils and reduced vapor diffusion on some silt loam soils.

Comparison of FAO-56 Evapotranspiration Against Measured Evapotranspiration from Multiple Sources

The FAO-56 simulated evaporation was compared against measured evaporation for six lysimeter and one Bowen ratio measured bare or near bare soil evaporation data sets. Detailed information about each data set is found in Appendix E by Burt et al. (2002). Three of the lysimeter data sets are from Bushland, Tex. (Howell et al. 1995), one is from Davis, Calif. (Parlange et al. 1992), one is from Temple, Tex. (Ritchie 1972), and one is from Kimberly, Id. (Wright, personal communication, 2002). The Bowen ratio data set was from Farahani and Bausch (1995). These data sets were selected because they appeared to have been collected with excellent quality controls.

Another FAO-56 simulation was run to compare data from Farahani and Bausch (1995) that used 12-h measurements with Bowen ratio equipment as an estimate of the daily evaporation. The FAO-56 simulation results matched those of the five lysimeter studies more closely than they did those of the Bowen ratio study. In the absence of other extended period evaporation measurements that used Bowen ratio equipment to compare against, 
Table 1. Range of FAO-56 Parameters for Defining Evaporation Reduction Coefficient $(\mathrm{Kr})$ Relationship for Loam, Silty Clay Loam, and Clay Soils [Derived from Allen et al. (1998)]

\begin{tabular}{|c|c|c|c|c|c|}
\hline Soils & $\begin{array}{c}\text { FAO-56 } \\
\theta_{F C}^{\text {a }} \text { range } \\
\left(\mathrm{m}^{3} \text { soil water } / \mathrm{m}^{3} \text { soil }\right)\end{array}$ & $\begin{array}{c}\text { FAO-56 } \\
\text { b range } \\
\theta_{W P}\left(\mathrm{~m}^{3} / \mathrm{m}^{3}\right)\end{array}$ & $\begin{array}{c}\text { FAO-56 } \\
\text { range of plant } \\
\text { available } \\
\text { water, } \theta_{F C}-\theta_{W P} \\
\left(\mathrm{~m}^{3} / \mathrm{m}^{3}\right)\end{array}$ & $\begin{array}{c}\text { FAO-56 } \\
\text { stage } 1 \\
\text { REW }^{\mathrm{c}} \text { range } \\
(\mathrm{mm})\end{array}$ & $\begin{array}{c}\text { FAO-56 } \\
\text { stage } 1 \text { and } 2 \\
\text { TEW }^{\mathrm{d}} \text { range } \\
(\mathrm{Ze}=0.1 \mathrm{~m})^{\mathrm{e}} \\
(\mathrm{mm})\end{array}$ \\
\hline Loam & $0.20-0.30$ & $0.07-0.17$ & $0.13-0.18$ & $8-10$ & $16-22$ \\
\hline Silty clay loam & $0.30-0.37$ & $0.17-0.24$ & $0.13-0.18$ & $8-11$ & $22-27$ \\
\hline Clay & $0.32-0.40$ & $0.20-0.24$ & $0.12-0.20$ & $8-12$ & $22-29$ \\
\hline
\end{tabular}

${ }^{\mathrm{a}} \theta_{F C}$ is the volumetric water content of the soil at field capacity.

${ }^{\mathrm{b}} \theta_{W P}$ is the volumetric water content of the soil at wilting point.

${ }^{\mathrm{c}} \mathrm{REW}$ : When the soil is at its peak water content, this is the amount of readily evaporable water.

${ }^{\mathrm{d}}$ TEW: When the soil is at its peak water content, this is the amount of Total Evaporable Water.

${ }^{\mathrm{e}} \mathrm{Ze}$ : Depth of surface soil layer that is subject to drying by way of evaporation.

the Farahani and Bausch (1995) data are listed but not included in Table 3 with the averages for the lysimeter studies.

The $E / \mathrm{ET}_{0}$ values estimated with the FAO-56 procedure closely tracked the measured values (Fig. 6), with a tendency to have either a similar or a more pronounced response to large precipitation or irrigation events and to have a smoother and smaller response to smaller events. An example of corresponding FAO-56 simulated and measured cumulative evaporation for experiments is displayed in Fig. 7. The average ratio of the mean daily modeled $E / \mathrm{ET}_{0}$ to the mean daily measured $E / \mathrm{ET}_{0}$ was 0.98 for the five lysimeter experiments. The average absolute value of the percent difference between the measured and the FAO-56 modeled cumulative evaporation for these experiments was $4.7 \%$ (Table 3 ).

\section{Bare Soil Evaporation without Stubble or Mulch}

\section{Impact of Soil Structure on Soil Evaporation}

Prihar et al. (1996) reported bare soil evaporation and the free water evaporation rate for soil columns. The soils in the columns were initially at field capacity moisture levels. This information is normalized in Table 4.
Our assumptions regarding available water and the choice of a $1 \mathrm{~m}$ soil depth for comparisons could be legitimately questioned. However, the following points clearly stand out, regardless of the precision of those assumptions:

1. For similar soil structure conditions (e.g., packed), finer textured soils have more inches of evaporation than do coarse textured soils in the same period of time.

2. The evaporation over a 64-day period extends quite deeply into the soil profile. Regardless of the exact number, it certainly extends much deeper than the $5-10 \mathrm{~cm}$ limit that might be imposed by some water balance computations. Structure has an important impact on the amount of evaporation as evidenced by the relatively low amount of water that evaporated from the "undisturbed" clay loam.

\section{Impact of Soil Cracking on Soil Evaporation}

One paper was found that specifically addressed the issue of evaporation from cracking soils. Using a precision lysimeter, Ritchie and Adams (1974) presented data to compare the relative evaporation, $E / \mathrm{ET}_{0}$ (grass reference potential ET) for bare soil with a 60 -cm-deep crack and for the same area with the bare soil (but not the crack) covered. The experiment was conducted at the

Table 2. FAO-56 Parameters Selected by the Writers to Determine Average Evaporation Reduction Coefficient (Kr) for Loam, Silty Clay Loam, and Clay Soils

\begin{tabular}{|c|c|c|c|c|c|c|c|}
\hline & $\begin{array}{c}\text { Chosen } \Theta_{F C}{ }^{\mathrm{a}} \text { to } \\
\text { obtain average } \\
\text { available water } \\
\left(\mathrm{m}^{3} \text { soil water } / \mathrm{m}^{3} \text { soil }\right)\end{array}$ & $\begin{array}{c}\text { Chosen } \Theta_{W P}{ }^{\mathrm{c}} \text { to } \\
\text { obtain average } \\
\text { available water }{ }^{\mathrm{b}} \\
\left(\mathrm{m}^{3} / \mathrm{m}^{3}\right)\end{array}$ & $\begin{array}{c}\text { FAO-56 } \\
\text { average plant } \\
\text { available water } \\
\Theta_{F C}-\Theta_{W P} \\
\left(\mathrm{~m}^{3} / \mathrm{m}^{3}\right)\end{array}$ & $\begin{array}{c}\text { Average FAO-56 } \\
\text { REW }^{\mathrm{d}} \\
(\mathrm{mm})\end{array}$ & $\begin{array}{l}\text { Computed } \\
\text { TEW }^{\mathrm{e}} \\
(Z e=0.1 \mathrm{~m})^{\mathrm{f}} \\
(\mathrm{mm})\end{array}$ & $\begin{array}{c}\text { Computed } \\
\text { TEW } \\
\theta_{F C}-0.5 \theta_{W P} \mathrm{~g} \\
\left(\mathrm{~m}^{3} / \mathrm{m}^{3}\right)\end{array}$ & $\begin{array}{c}\text { Final water } \\
\text { content } \\
\theta_{F C}-\mathrm{TEW} \\
\left(\mathrm{m}^{3} / \mathrm{m}^{3}\right)\end{array}$ \\
\hline Loam & 0.263 & 0.108 & 0.155 & 9.0 & 20.9 & 0.209 & 0.054 \\
\hline Silty clay loam & 0.350 & 0.195 & 0.155 & 9.5 & 25.3 & 0.253 & 0.098 \\
\hline Clay & 0.375 & 0.215 & 0.160 & 10.0 & 26.8 & 0.268 & 0.108 \\
\hline
\end{tabular}

${ }^{\mathrm{a}} \theta_{F C}$ is the volumetric water content of the soil at field capacity.

${ }^{\mathrm{b}}$ ITRC chosen $\theta_{F C}$ and $\theta_{W P}$ were as near to their mean value as possible while still yielding the average possible FAO-56 available water for the given soil type.

${ }^{\mathrm{c}} \theta_{W P}$ is the volumetric water content of the soil at wilting point.

${ }^{\mathrm{d}} \mathrm{REW}$ : When the soil is at its peak water content, this is the depth of readily evaporable water.

${ }^{\mathrm{e}}$ TEW: When the soil is at its peak water content, this is the depth of total evaporable water.

${ }^{\mathrm{f}} \mathrm{Ze}$ : Depth of surface soil layer that is subject to drying by way of evaporation.

${ }^{g}$ FAO-56 assumes the TEW for a soil has been depleted when the volumetric soil water content is reduced to half of the $\theta_{W P}$ for the soil. 


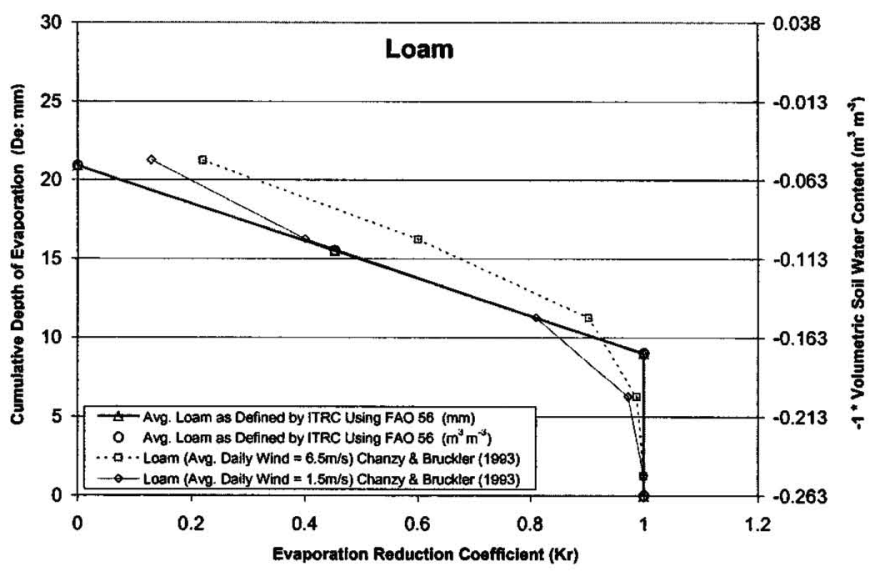

Fig. 3. Comparison of the measured loam (Avignon, France) $\mathrm{Kr}$ relationships derived from Chanzy and Bruckler (1993) against the $\mathrm{Kr}$ relationship of an average loam soil using FAO-56.

end of the 1967 grain sorghum growing season on a Houston black clay composed of $55 \%$ montmorillonite clay, in Temple, Tex. Because the evaporation from the ground surface area was the parameter of interest, the measured evaporation rates were calculated based on the ground surface area of the lysimeter and not the exposed soil surface area, which was larger due to the presence of a naturally occurring $60-\mathrm{cm}$-deep crack that extended for the full length of the lysimeter (Fig. 8). Table 5 demonstrates that the 5-day relative soil evaporation was nearly identical when the crack was the only exposed soil area and when both the crack and the remaining bare soil in the lysimeter were exposed. Therefore, most of the evaporation was coming from the crack.

Ritchie and Adams (1974) suggested that near the end of the sorghum growing season the evaporation from the cracks could be $0.5 \mathrm{~mm} /$ day. If rain does not occur for 30 more days, there might be an additional $15 \mathrm{~mm}$ of soil water lost to evaporation before the cracks swell closed from the rains. They felt that this loss may not be significant as compared to the $300-400 \mathrm{~mm}$ of seasonal water use by this crop. However, they recognized that at some locations there can be little postseason rain and that this could result in a desire to conserve soil water by minimizing the evaporative loss from the cracks. They mentioned one possible

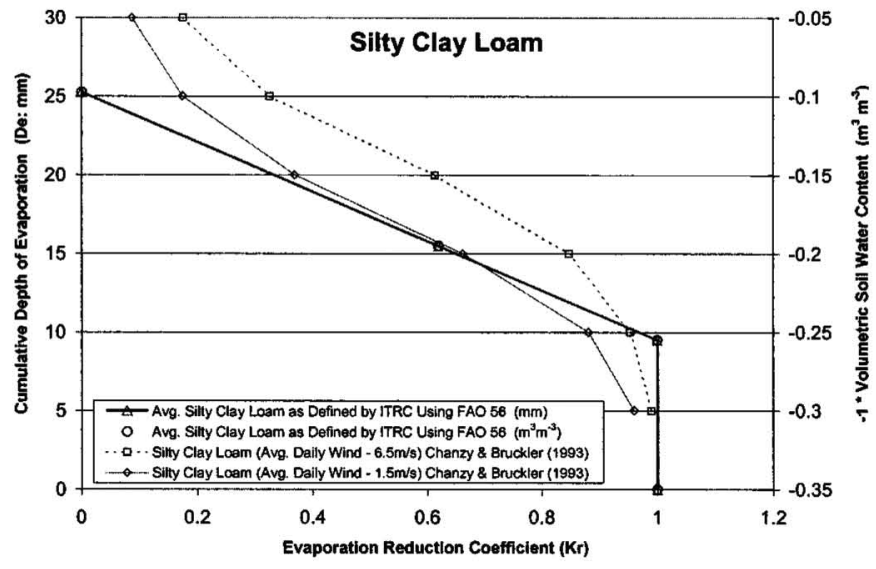

Fig. 4. Comparison of the measured silty clay loam (Avignon, France) $K r$ relationships derived from Chanzy and Bruckler (1993) against the $K r$ relationship of an average silty clay loam using FAO56.

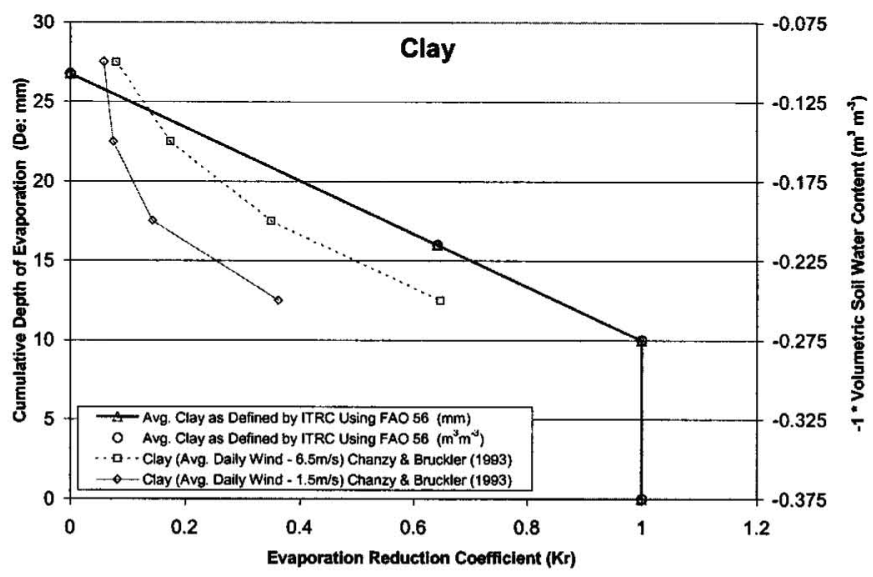

Fig. 5. Comparison of the measured clay (Avignon, France) $K r$ relationships derived from Chanzy and Bruckler (1993) against the $\mathrm{Kr}$ relationship of an average clay using FAO-56.

method for helping to minimize this loss: filling the cracks with mulch, a process that might be difficult on a field scale. Yates et al. (1996) mentioned applying plastic over whole fields, but this would almost certainly be uneconomical and would interfere with precipitation storage in all but extremely arid environments.

\section{Soil Evaporation and the Depth of Water Extraction}

Shawcroft and Gardner (1983) presented short-term relative evaporation observations following solid-set irrigation of corn for a Weld silt loam soil in Akron, Colo. (Table 6).

The reported values were averages from microlysimeters that were spatially distributed to obtain the average soil evaporation from under the crop canopy. These data support the important observation that even when considering soil evaporation for a relatively short period of time (12 days) after an irrigation event, some of the soil water removed by evaporation can come from depths that are below the $5-10 \mathrm{~cm}$ limit that might be imposed by some water balance computations.

\section{Effect of Stubble and Mulch on Soil Evaporation in the Field}

\section{General Statement of Effect}

The reduction in soil evaporation where stubble remains from a previous crop or where mulches are added to the soil surface has been evaluated with fair rigor in the literature. The effects of conventional tillage and no-till stubble treatments have also been assessed. Stubbles and mulches reduce soil evaporation by providing a mechanical barrier to the drying forces of wind, and they shield the soil surface from solar radiation. Mulches also buffer the connection between the water vapor in the soil and the air above. Before presenting observed evaporation reduction from some of the studies, it seems appropriate to briefly describe how microlysimeters are often used in these and other soil evaporation studies.

\section{Microlysimeters}

Microlysimeters are typically tubes that are inserted into the soil in a manner that minimizes the disturbance of the soil structure, with the maintenance of the upper soil structure being most critical. The tubes are then typically removed from the soil and measurements of the adjacent soils are made to estimate the water 
Table 3. Comparison of FAO-56 Simulated Evaporation Against Various Field Measurements of Evaporation

\begin{tabular}{|c|c|c|c|c|c|c|}
\hline & $\begin{array}{l}\text { Ritchie } \\
(1972)\end{array}$ & $\begin{array}{l}\text { Parlange } \\
\text { and Katul } \\
(1992)\end{array}$ & $\begin{array}{l}\text { Howell } \\
\text { et al. } \\
(1995)\end{array}$ & $\begin{array}{l}\text { Howell } \\
\text { et al. } \\
(1995)\end{array}$ & $\begin{array}{l}\text { Howell } \\
\text { et al. } \\
(1995)\end{array}$ & $\begin{array}{l}\text { Farahani and } \\
\text { Bausch } \\
\text { (1995) }\end{array}$ \\
\hline Year measurements were collected & 1969 & 1990 & 1989 & 1991 & 1992 & 1993 \\
\hline Measurement method & Lysimeter & Lysimeter & Lysimeter & Lysimeter & Lysimeter & $\begin{array}{c}\text { Bowen ratio } \\
\text { equipment }\end{array}$ \\
\hline $\begin{array}{l}\text { Number of days from start to end } \\
\text { of the evaluated period }\end{array}$ & 12 & 10 & 31 & 41 & 40 & 25 \\
\hline Rain of irrigation during the period (mm) & 48.4 & 18.1 & 74.0 & 104.8 & 95.7 & 56.1 \\
\hline $\begin{array}{l}\text { Measured cumulative bare soil } \\
\text { evaporation }(\mathrm{mm})\end{array}$ & 24.2 & 16.8 & 52.8 & 93.7 & 81.2 & 60.3 \\
\hline $\begin{array}{l}\text { FAO- } 56 \text { modeled cumulative bare soil } \\
\text { evaporation }(\mathrm{mm})\end{array}$ & 24.7 & 18.3 & 51.5 & 87.9 & 84.4 & 47.1 \\
\hline $\begin{array}{l}\text { Absolute value of the percentage } \\
\text { difference between measured and } \\
\text { FAO-56 modeled cumulative } E\end{array}$ & $2.1 \%$ & $8.9 \%$ & $2.4 \%$ & $6.1 \%$ & $3.9 \%$ & $21.9 \%$ \\
\hline $\begin{array}{l}\text { Ratio of mean daily FAO- } 56 \text { modeled } \\
E / \mathrm{ET}_{0} \text { to mean daily measured } E / \mathrm{ET}_{0}\end{array}$ & 1.03 & 0.84 & 0.85 & 1.11 & 1.06 & 0.85 \\
\hline \multicolumn{3}{|c|}{$\begin{array}{l}\text { Average percentage difference between lysimeter } E \\
\text { value versus FAO-56 modeled cumulative } E\end{array}$} & \multicolumn{4}{|c|}{4.7} \\
\hline \multicolumn{3}{|c|}{$\begin{array}{l}\text { Average of lysimeter experiment ratios of mean } \\
\text { daily } \mathrm{FAO}-56 \text { modeled } E / \mathrm{ET}_{0} \text { to mean daily } \\
\text { measured } E / \mathrm{ET}_{0}\end{array}$} & \multicolumn{4}{|c|}{0.98} \\
\hline
\end{tabular}

content and bulk density of the soil in the microlysimeters. The bottoms of the microlysimeters are capped and returned to the soil. The amount of water lost by evaporation is determined daily by weighing the microlysimeters at sunrise and at sunset. R. Lascano (personal communication, 2001) noted that obtaining accurate soil evaporation measurements with microlysimeters is an art. Using many spatially distributed replications of microlysimeters helps to capture the average soil evaporation that occurs within the plant/soil environment (Shawcroft and Gardner 1983; Lascano and van Bavel 1986; Staggenborg et al. 1996).

Evett et al. (1995b) identified the following key points to improve the accuracy of microlysimeter evaporation measurements:

1. Tube walls should have low thermal conductivity (PVC) so they do not artificially transmit surface heat energy downward, effectively reducing evaporation.

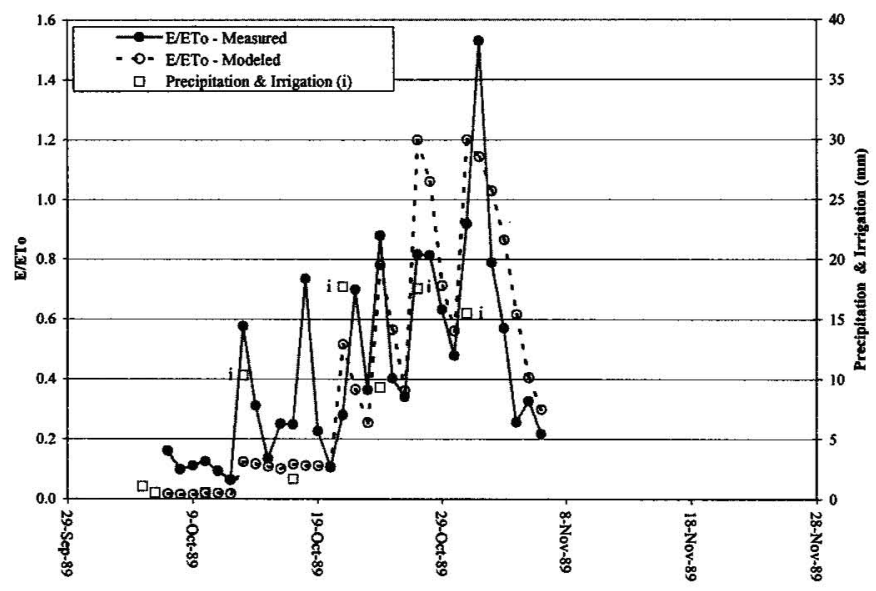

Fig. 6. Comparison of bare soil $E / E T_{0}$ ratios. Lysimeter measured (in 1989 at Bushland, Tex.-Pullman clay loam - reported by Howell et al. 1995) and FAO-56 model results.
2. The bottom of the tube should be capped so that soil contact with both sides of the cap is maximized, as is heat transfer through the cap, and vertical water movement is eliminated. A thin, perhaps flexible metal cap is suggested.

3. When tubes were left in the field for 9 days, measurement errors were minimized when the tube length was at least $0.3 \mathrm{~m}$ in length.

4. The microlysimeter wall and capping material should be identified and lysimeter dimensions stated. In addition, it would be helpful to identify

- The lysimeter installation method;

- Whether (and how) water was added to the soil in the tube;

- The spatial distribution of the measurements;

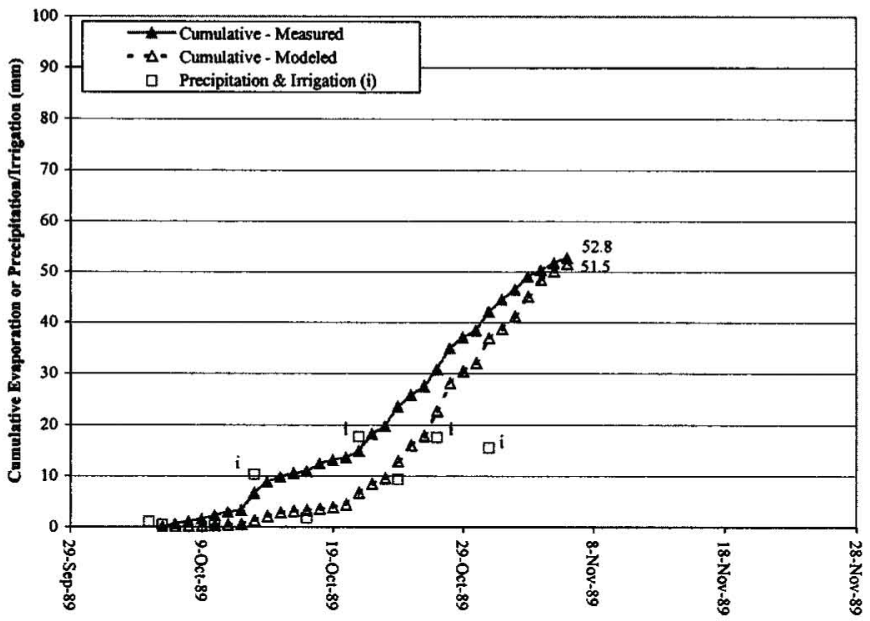

Fig. 7. Comparison of bare soil cumulative evaporation. Lysimeter measured (in 1989 at Bushland, Tex.-Pullman clay loam-reported by Howell et al. 1995) and FAO-56 model results. 


\begin{tabular}{|c|c|c|c|c|c|c|c|c|c|}
\hline $\begin{array}{l}\text { Soil } \\
\text { texture }\end{array}$ & Condition & $\begin{array}{c}\text { Bulk } \\
\text { density } \\
\left(\mathrm{Mg} \mathrm{m}^{-3}\right)\end{array}$ & $\begin{array}{c}\text { Evaporation } \\
(\mathrm{mm})\end{array}$ & $\begin{array}{c}\text { Free water } \\
\text { evaporation }(\mathrm{mm}) \\
(\text { control })\end{array}$ & $\begin{array}{l}\text { Days of the } \\
\text { experiment }\end{array}$ & $\begin{array}{l}\text { Estimated } \\
\text { water in } \\
\text { top meter of } \\
\text { soil (field } \\
\text { capacity } \\
\text { air dry) } \\
(\mathrm{mm})\end{array}$ & $\begin{array}{c}\text { Estimated } \\
\text { percentage } \\
\text { of water in } \\
\text { upper meter } \\
\text { that } \\
\text { evaporated }^{\mathrm{b}}\end{array}$ & $\begin{array}{c}\text { Water } \\
\text { fraction by } \\
\text { mass at } \mathrm{FC}^{\mathrm{bc}}\end{array}$ & $\begin{array}{c}\text { Millimeters water } \\
\text { per millimeters } \\
\text { of soib }{ }^{\text {bc }}\end{array}$ \\
\hline $\begin{array}{l}\text { Silt } \\
\text { loam }\end{array}$ & Packed & 1.29 & 95 & 640 & 64 & 258 & 37 & .20 & .258 \\
\hline $\begin{array}{l}\text { Sandy } \\
\text { loam }\end{array}$ & Packed & 1.38 & 80 & 640 & 64 & 97 & 83 & .07 & .097 \\
\hline $\begin{array}{l}\text { Loamy } \\
\text { sand }\end{array}$ & Packed & 1.45 & 40 & 640 & 64 & 73 & 55 & .05 & .073 \\
\hline $\begin{array}{l}\text { Pullman } \\
\text { clay } \\
\text { loam }\end{array}$ & Undisturbed & $\begin{array}{c}\text { Not } \\
\text { given } \\
1.55 \\
\text { assumed }\end{array}$ & 30 & 313 & 25 & 341 & 9 & .22 & .341 \\
\hline
\end{tabular}

- Whether the microlysimeters at specific locations were replaced or reused, or whether a new lysimeter was installed at a different location; and

- The frequency of any microlysimeter procedure.

Table 7 identifies this information for the four studies evaluated in this review that used microlysimeters to measure soil evaporation.

\section{Observed Short-Term Soil Evaporation Reduction with Mulch}

Hares and Novak (1992) used microlysimeters to measure the differences in soil evaporation on June 14, 1984, between four uniformly spread straw-mulch treatments where conventional tillage (CT) practices were used. The tillage consisted of soil disking and firm packing of a Bose loamy sand in Vancouver, BC, and the treatments excluded a crop. Although the irrigation type, amount, and timing were not identified, the relative reduction is of interest.

Table 8 demonstrates the benefit that no-till and increased surface residue can have on short-term evaporation. For this study, it is perhaps more important to understand the long-term impact of these and other factors on soil evaporation.

\section{Observed Seasonal Soil Evaporation Reduction with Stubble and Mulch}

Brun et al. (1986) used large weighing lysimeters to measure cumulative evaporation for April and May from a Fargo-Ryan silty clay soil (Fargo, N.D.) that was conventionally tilled in the fall and from areas that had wheat stubble with no tillage. A crop

Table 5. Relative Evaporation for Crack in Houston Black Clay with and without Contribution of Evaporation from Soil Adjacent to Crack [Derived from Ritchie and Adams (1974)]

\begin{tabular}{|c|c|c|}
\hline Treatment & $\begin{array}{l}5 \text {-day evaluation } \\
\text { periods }\end{array}$ & $\begin{array}{c}\text { 5-day } E / \mathrm{ET}_{0}{ }^{\mathrm{a}} \\
(\mathrm{mm} / \mathrm{mm})\end{array}$ \\
\hline $\begin{array}{l}\text { Bare soil and crack } \\
\text { exposed to evaporation }\end{array}$ & $\begin{array}{c}\text { September 9-October 13, } \\
1967\end{array}$ & $3.7 / 24.6=0.15$ \\
\hline $\begin{array}{l}\text { Crack only exposed to } \\
\text { evaporation }\end{array}$ & $\begin{array}{c}\text { September } 28-\text { October 2, } \\
1967\end{array}$ & $3.0 / 18.5=0.16$ \\
\hline
\end{tabular}

was excluded from the 2 years that were evaluated, and the water input was from rain only $($ dryland $=D)$. In 1982, there were $56 \mathrm{~mm}$ of light rain, and in 1984 there were $70 \mathrm{~mm}$ of heavier rain (Table 9).

Lascano et al. (1994) reported the cumulative 100-day soil evaporation for the two treatments. These treatments were conventional tillage and stubble/no-till (NT) treatments for cotton on an Olton sandy clay loam soil in Lubbock, Tex. Depending on the placement in the NT treatment, some of the microlysimeters had stubble protruding from the top of the lysimeter. The conventional tillage consisted of shredding the winter wheat stubble, moldboard and disk plowing twice, and then ridge tilling to match the beds for the stubble covered no-till treatment (rate of stubble was not identified). The rainfall and furrow irrigation total was $325 \mathrm{~mm}$ and, for comparison with another study, we will identify this as limited irrigation $(L)$. The stubble/no-till treatment had $39 \%$ less soil evaporation than the CT treatment with no stubble or mulch (Table 10).

The measurement of $E$ before crop development in the CT treatment may have been low if the microlysimeters were in fact made of aluminum as is suspected. For the NT treatment, early measured $E$ may have also been low, but would probably not have

Table 6. Soil Evaporation As a Function of Soil Depth for Weld Silt Loam [Derived from Shawcroft and Gardner (1983)]

\begin{tabular}{lcc}
\hline $\begin{array}{l}\text { Days of } \\
\text { measured } \\
\text { evaporation }\end{array}$ & $\begin{array}{c}\text { Microlysimeter } \\
\text { depth }(\mathrm{cm})\end{array}$ & $E / E_{p}{ }^{\mathrm{c}}$ \\
\hline $16^{\mathrm{a}}$ & 20 & $33 / 40=0.83$ \\
16 & 10 & $27 / 40=0.68$ \\
$12^{\mathrm{b}}$ & 20 & $27.5 / 32=0.86$ \\
12 & 10 & $15.5 / 32=0.48$ \\
\hline $\mathrm{a} J u l y ~ 8-24,1975$. & \\
${ }^{\mathrm{b}} \mathrm{July} 8-21,1976$. & \\
${ }^{\mathrm{c}} E$ is the cumulative soil evaporation for the measurement period (mm) \\
and $E_{p}$ is the potential soil evaporation for the period (mm) as calculated \\
with a simplified Penman equation using the net radiation that reaches \\
the soil surface. The equation neglects wind, resistance terms, and \\
vapor diffusion.
\end{tabular}




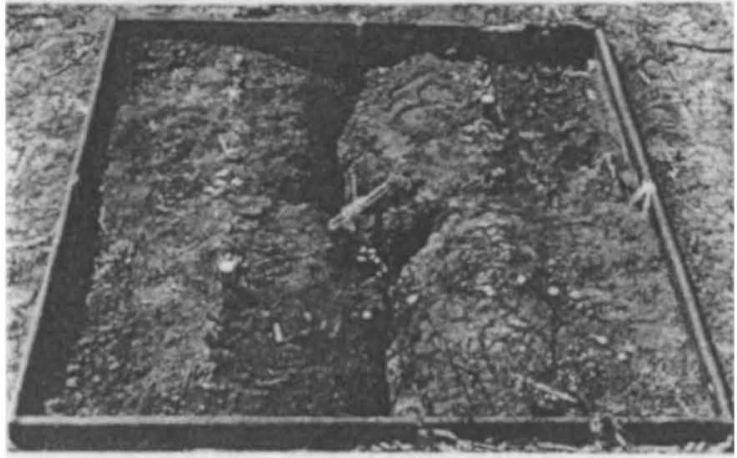

Fig. 8. Lysimeter with Houston black clay soil used by Ritchie and Adams (1974) to demonstrate the contribution to soil evaporation made by naturally occurring soil cracks. (Reproduced with permission of the Soil Society of America.) been impacted as significantly as the CT treatment because there would have been shading from the standing stubble. Effectively then, it is possible that the true $E$ reduction from the NT treatment was somewhat larger than the $39 \%$ listed in Table 10.

Todd et al. (1991) offers insight on how soil evaporation for Cozad silt loam (North Platte, Neb.) is influenced not only by residue but also by the amount of water input for bare soil (Table 11) and for a crop (Table 12). The water inputs were $153 \mathrm{~mm}$ for the dryland treatment $(D), 300 \mathrm{~mm}$ for the limited irrigation treatment $(L)$, and 550 for the full irrigation treatment $(F)$. Solid set sprinklers were used to irrigate beyond the rainfall amount, and soil evaporation was measured with microlysimeters.

\section{General Conclusions About the Effects of Stubble and Surface Mulches on Soil Evaporation}

1. The amount of short-term (and probably long-term) soil evaporation reduction increases with an increase in the rate of a soil surface mulch (Table 8).

Table 7. Specifications of Microlysimeters Used in Studies Evaluated in This Paper

\begin{tabular}{|c|c|c|c|c|c|}
\hline Study & $\begin{array}{c}\text { Material } \\
\text { (tube walls/Cap) }\end{array}$ & $\begin{array}{l}\text { Dimensions } \\
\quad \text { (inside } \\
\text { diameter }(\mathrm{cm}) / \\
\text { height }(\mathrm{cm}))\end{array}$ & $\begin{array}{l}\text { Measurement } \\
\text { period } \\
\text { (day) }\end{array}$ & $\begin{array}{l}\text { Microlysimeter } \\
\text { (ML) spatial } \\
\text { distribution }\end{array}$ & $\begin{array}{l}\text { Microlysimeter } \\
\text { handling }\end{array}$ \\
\hline $\begin{array}{l}\text { Hares and } \\
\text { Novak (1992) }\end{array}$ & $\begin{array}{c}\text { Standard } \\
\text { bulk density } \\
\text { cores }^{\mathrm{a}} / \text { tape }\end{array}$ & $7.4 / 15.2$ & 1 & $\begin{array}{l}\text { Two ML } \\
\text { replicates per } \\
\text { treatment }\end{array}$ & $\begin{array}{l}\text { Installed (no method } \\
\text { stated) the night } \\
\text { before the day of } \\
\text { interest; weighed every } \\
2 \mathrm{~h} \text { in the daytime }\end{array}$ \\
\hline $\begin{array}{l}\text { Lascano } \\
\text { et al. (1994) }\end{array}$ & $\begin{array}{l}\text { Aluminum }{ }^{\mathrm{b}} / \\
\text { Aluminum foil }\end{array}$ & $7.4 / 13$ & 12.5 and 25.5 & $\begin{array}{l}10 \mathrm{ML} \\
\text { replicates per } \\
\text { treatment all } \\
\text { placed in the row }\end{array}$ & $\begin{array}{l}\text { Similar to Todd et al. } \\
\text { (1991), however, soil } \\
\text { wall retention cylinders } \\
\text { were not used }\end{array}$ \\
\hline $\begin{array}{l}\text { Todd et al. } \\
\text { (1991) }\end{array}$ & $\begin{array}{c}\text { PVC/ } \\
\text { Galvanized tin }\end{array}$ & $15 / 22.5$ & 125 & $\begin{array}{l}\text { At least one ML } \\
\text { for each of the } \\
\text { three replicates } \\
\text { of the three wetting } \\
\text { regimes and various } \\
\text { soil surface treatments }\end{array}$ & $\begin{array}{l}\text { ML pushed into soil } \\
\text { by tractor-mounted } \\
\text { hydraulic soil } \\
\text { sampler. } \\
\text { ML was excavated } \\
\text { and bottom-capped. } \\
\text { MLs were snuggly } \\
\text { fit into holes in the } \\
\text { field that used open-ended } \\
\text { sheet metal cylinders } \\
\text { as soil retaining walls. } \\
\text { ML weights recorded daily. } \\
\text { ML removed before } \\
\text { irrigations, nearby } \\
\text { volumetric soil water } \\
\text { contents were } \\
\text { determined, and water } \\
\text { was added to the top } \\
\text { of the MLs to match } \\
\text { the corresponding } \\
\text { locations. }\end{array}$ \\
\hline $\begin{array}{l}\text { Shawcraft and } \\
\text { Gardner (1983) }\end{array}$ & PVC/sheet metal & $19.7 / 10$ and 20 & 12 and 16 & $\begin{array}{l}\text { Two ML of each } \\
\text { depth were placed } \\
\text { in the row and } \\
\text { two were placed } \\
\text { between the rows }\end{array}$ & $\begin{array}{l}\text { MLs handled in a very } \\
\text { similar manner as } \\
\text { Todd et al. (1991) }\end{array}$ \\
\hline
\end{tabular}

\footnotetext{
${ }^{a}$ Material was not specifically identified.

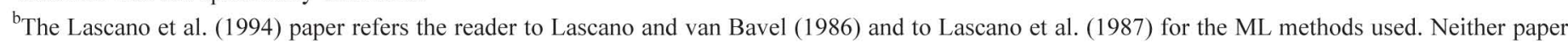
identified the ML material; however, Lascano and Hatfield refers to the same two papers and specifically states that the ML material was aluminum with the same dimensions as those identified in Lascano and van Bavel (1986).
} 
Table 8. Effect of Surface Mulch Rates on 1 Day of Evaporation from Bare Loamy Sand Soil [Derived from Hares and Novak (1992)]

\begin{tabular}{lcc}
\hline Treatment $^{\mathrm{a}}$ & $\begin{array}{c}\text { Daily } E \\
(\mathrm{~mm})\end{array}$ & $\begin{array}{c}\text { Percentage } E \\
\text { reduction }\end{array}$ \\
\hline $\mathrm{CT}^{\mathrm{b}}$, no crop and no mulch & 1.9 & - \\
$\mathrm{CT}$, no crop and $907 \mathrm{~kg} / \mathrm{ha}^{-1}$ spread & 1.7 & 11 \\
straw & & \\
$\mathrm{CT}$, no crop and $9,070 \mathrm{~kg} / \mathrm{ha}^{-1}$ spread & 0.6 & 68 \\
straw & & \\
$\mathrm{CT}$, no crop and $18,140 \mathrm{~kg} / \mathrm{ha}^{-1}$ spread & 0.3 & 84 \\
straw & & \\
\hline
\end{tabular}

${ }^{\mathrm{a}}$ Irrigation method, timing, and amount were not stated.

${ }^{\mathrm{b}} \mathrm{CT}=$ conventional tillage.

Table 9. 2-Month Soil Evaporation Reduction Using No-Till with Standing Stubble for Bare Fargo-Ryan Silty Clay Soil in Dryland Conditions [Derived from Brun et al. (1986)]

\begin{tabular}{lcc}
\hline Treatment & $\begin{array}{c}\text { 2-month } E \\
(\mathrm{~mm})\end{array}$ & $\begin{array}{c}\text { Percentage } E \\
\text { reduction }\end{array}$ \\
\hline$D^{\mathrm{a}}, \mathrm{CT}^{\mathrm{b}}$, no crop and no mulch-1982 & 65 & - \\
$D, \mathrm{NT}^{\mathrm{c}}$, no crop and $4,500 \mathrm{~kg} / \mathrm{ha}^{-1}$ standing & 58 & 11 \\
stubble-1982 & & \\
$D, \mathrm{CT}$, no crop and no mulch-1984 & 65 & - \\
$D, \mathrm{NT}$, no crop and $3,400 \mathrm{~kg} / \mathrm{ha}^{-1}$ standing & 52 & 20
\end{tabular}

stubble-1984

aryland: $56 \mathrm{~mm}$ of light rain in 1982 and $70 \mathrm{~mm}$ of heavier rain in 1984.

${ }^{\mathrm{b}}$ Conventional tillage.

${ }^{\mathrm{c}}$ No-till with standing stubble.

Table 10. 100-Day Soil Evaporation Reduction Using No-Till and Planting in Standing Stubble for Olton Sandy Clay Loam with Limited Irrigation [Derived from Lascano et al. (1994)]

\begin{tabular}{lcc}
\hline Treatment & $\begin{array}{c}100 \text {-day } E \\
(\mathrm{~mm})\end{array}$ & $\begin{array}{c}\text { Percentage } E \\
\text { reduction }\end{array}$ \\
\hline$L^{\mathrm{a}}, \mathrm{CT}^{\mathrm{b}}$, cotton and no mulch & 162 & - \\
$L, \mathrm{NT}^{\mathrm{c}}$, cotton and standing stubble & 100 & 39
\end{tabular}

${ }^{\mathrm{a}}$ Limited irrigation- $325 \mathrm{~mm}$ of rain and furrow irrigation.

${ }^{\mathrm{b}}$ Conventional tillage.

${ }^{\mathrm{c}}$ No-till with standing stubble.

Table 11. One Hundred Twenty Five Day Soil Evaporation Reduction Using Surface Mulch on Bare Cozad Silt Loam Soil for Three Irrigation Conditions [Derived from Todd et al. (1991)]

\begin{tabular}{lcc}
\hline Treatment & $\begin{array}{c}\text { 125-day } E \\
(\mathrm{~mm})\end{array}$ & $\begin{array}{c}\text { Percentage } E \\
\text { reduction }\end{array}$ \\
\hline$D^{\mathrm{a}}, \mathrm{CT}^{\mathrm{b}}$, no crop and no mulch & 122 & - \\
$D, \mathrm{CT}$, no crop and $6,700 \mathrm{~kg} / \mathrm{ha}^{-1}$ spread straw & 122 & 0 \\
$L^{\mathrm{c}}, \mathrm{CT}$, no crop and no mulch & 160 & - \\
$L, \mathrm{CT}$, no crop and $6,700 \mathrm{~kg} / \mathrm{ha}^{-1}$ spread straw & 120 & 25 \\
$F^{\mathrm{d}}, \mathrm{CT}$, no crop and no mulch & 235 & - \\
$F, \mathrm{CT}$, no crop and $6,700 \mathrm{~kg} / \mathrm{ha}^{-1}$ spread straw & 125 & 47
\end{tabular}

${ }^{\mathrm{a} D r y l a n d}-153 \mathrm{~mm}$ of rain input only.

${ }^{\mathrm{b}}$ Although not specifically stated, since there was no reference made to there having been standing stubble for the treatments in this table, it is assumed that all of the treatments underwent conventional tillage.

${ }^{\mathrm{c}}$ Limited irrigation- $300 \mathrm{~mm}$ of rain and solid-set sprinkler irrigation.

${ }^{\mathrm{d}}$ Full irrigation- $550 \mathrm{~mm}$ of rain and solid-set sprinkler irrigation.
Table 12. One Hundred Twenty Five Day Soil Evaporation Reduction Using No-Till and Planting in Standing Stubble with Addition of Surface Mulch to Cozad Silt Loam Soil for Three Irrigation Conditions [Derived from Todd et al. (1991)]

\begin{tabular}{|c|c|c|}
\hline Treatment & $\begin{array}{l}\text { 125-day } \\
E(\mathrm{~mm})\end{array}$ & $\begin{array}{l}\text { Percentage } E \\
\text { reduction }\end{array}$ \\
\hline $\begin{array}{l}D^{\mathrm{a}}, \mathrm{NT}^{\mathrm{b}} \text {, corn and standing corn stubble- } \\
\text { no spread straw on microlysimeters }\end{array}$ & 80 & - \\
\hline $\begin{array}{l}D, \mathrm{NT} \text {, corn and standing wheat stubble- } \\
\text { spread straw on microlysimeters }\end{array}$ & 80 & 0 \\
\hline $\begin{array}{l}L^{\mathrm{d}}, \mathrm{NT} \text {, corn and standing corn stubble- } \\
\text { no spread straw on microlysimeters }\end{array}$ & 120 & - \\
\hline $\begin{array}{l}L, \mathrm{NT} \text {, corn and standing wheat stubble- } \\
\text { spread straw on microlysimeters }\end{array}$ & 76 & 37 \\
\hline $\begin{array}{l}F^{\mathrm{e}} \text {, NT, corn and standing corn stubble- } \\
\text { no spread straw on microlysimeters }\end{array}$ & 125 & - \\
\hline $\begin{array}{l}F, \mathrm{NT} \text {, corn and standing wheat stubble- } \\
\text { spread straw on microlysimeters }\end{array}$ & 62 & 50 \\
\hline \multicolumn{3}{|l|}{${ }^{\mathrm{a}}$ Dryland $-153 \mathrm{~mm}$ of rain input only. } \\
\hline \multicolumn{3}{|l|}{${ }^{\mathrm{b}}$ No-till with standing stubble. } \\
\hline \multicolumn{3}{|c|}{${ }^{\mathrm{c}}$ Rate of spread straw on lysimeter for this table $=6,700 \mathrm{~kg} / \mathrm{ha}^{-1}$. } \\
\hline \multicolumn{3}{|c|}{${ }^{\mathrm{d}}$ Limited irrigation $-300 \mathrm{~mm}$ of rain and solid-set sprinkler irrigation. } \\
\hline
\end{tabular}

2. Using no-till versus conventional tillage practices reduces soil evaporation (Tables 9-11).

3. All other conditions being equal, soil surface mulches are not effective at reducing soil evaporation under dryland conditions for both fallow and cropped conditions (Tables 11 and 12).

4. For bare soil conditions during an extended period of time, the amount of evaporation increases as water input increases. In contrast, for bare soil conditions with mulch spread over the soil surface, the amount of soil evaporation is nearly identical for any amount of water input. This is an example of how surface mulches enhance a soil's ability to store water (Table 11).

5. When rainfall is supplemented with irrigation, adding soil surface mulches reduces soil evaporation (Tables 11 and 12).

6. The percentage of soil evaporation reduction increases with an increase in irrigation amount (Tables 11 and 12).

7. For production agriculture that relies on supplemental irrigation, combinations of no-till, planting in standing stubble, and applying surface mulches have been shown to reduce seasonal soil evaporation by about 35 to $50 \%$, depending on the irrigation amount (Tables 10 and 12).

8. Robert Lascano (personal communication, 2000) stated that the precision in measuring soil evaporation in the field does not currently allow one to discern a difference in the evaporation from standing stubble and stubble that has been cut at the root and tends to lay flat. However, in the laboratory he has shown that standing stubble acts like a wick through which soil water can be transmitted and lost to the atmosphere. He stated that the rate of loss is small and difficult to detect with current technologies. He stated that if the rate is $0.5 \mathrm{~mm} /$ day, the seasonal loss could be significant. Until this effect is more clearly understood, when maximum soil water conservation is critical, using the semi-no-till approach of cutting the roots of stubble may be appropriate.

9. Lascano also noted (personal communication, 2000) that when one considers the water use efficiency of a crop that is planted in stubble from the same growing season, the water 
used to grow the crop that is the stubble must be accounted.

10. Longer and very well controlled field studies may be needed to identify whether the measured 100 and 125 day $E$ reductions shown in Tables 10-12 would persist when the time frame of consideration is a year or more. At some point, soil moisture storage limitations will cause mulched and nonmulched cumulative evaporation to be identical.

\section{Soil Evaporation with Drip Irrigation}

Discussions with irrigation dealers and farmers almost always bring out their opinion that evaporation is considerably less with drip irrigation than with other irrigation methods. Conversations with and a search of publications by academics and researchers, however, gave less credence to the notion of reduced soil evaporation on typical drip/micro systems.

\section{Interviews and Observations}

D. C. Kincaid (personal communication 2000), noted that in USDA/ARS Idaho field comparisons between sprinkler and drip irrigation he was not able to measure daily differences in evaporation between the methods. However, the ET (scheduling) model he uses estimates that for a bare soil condition the difference in surface evaporation between surface drip (or furrow) with partial wetting and sprinkler with full wetting could be as much as $50 \%$ of the potential ET for the first day after an irrigation or until the surface is visually dry. As the crop approaches full cover, this difference is reduced to probably less than $5 \%$. On an overall seasonal basis, Kincaid estimated that overall water use efficiency when using surface-drip versus center-pivot or linear-move, is increased by 5 to $10 \%$.

Hsiao of the Univ. of California, Davis ( $\mathrm{T}$. Hsiao, personal communication, 2000) is conducting research to identify potential savings in soil evaporation $(E)$ by using surface-drip as opposed to furrow. He notes that drip can reduce evaporation under two conditions:

1. When the crop or tree canopy cover is less than $100 \%$

2. When the soil is light textured with low water holding capacity. When the texture is light (i.e., sandy), the required time between furrow irrigations is sometimes reduced to 5 days, resulting in more opportunity for soil evaporation to occur.

The second point can be explained by the logic that under complete crop cover or when there is a good heavy soil, soil evaporation from surface-drip is similar to that under furrow irrigation. This is because, although the drip wets a smaller area, that area is wet for much of the growing season; whereas, with furrow irrigation, more of the surface area is wetted, but it dries, reducing the amount of soil evaporation.

\section{Literature on Soil Evaporation with Drip Irrigation}

Subsurface Drip (SDI). Burt et al. (1997) noted that crop ET $\left(\mathrm{ET}_{c}\right)$ will be less for a well-watered crop with dry soil and plant surfaces (as can be the case with SDI) than if the crop was irrigated with a method that wets the soil and plant surfaces. Further, the method that wets the soil surface can also result in more weed development and loss of applied water through weed transpiration. Evett et al. (1995a) identified that for treatments with similar canopy development, there is no difference in seasonal ET of drip irrigation and furrow irrigation. Evett et al. (1995a) hypothesized that improved yields for subsurface systems are most likely due to more water being available to the plants irrigated with those systems since, relative to surface-drip, less of the applied water is lost to evaporation.

Using field measurements, Evett et al. (2000) compared surface- and subsurface-drip irrigation treatments for a corngrowing season in Bushland, Tex. using the coupled mechanistic water and energy balance model ENWATBAL. The treatments evaluated were surface and 0.15 and $0.30 \mathrm{~m}$ depth SDI. Daily irrigation was scheduled to replace crop water use as measured with a neutron probe. Modeled transpiration was nearly identical for the three irrigation methods (about $430 \mathrm{~mm}$ over 114 days following emergence), but soil evaporation for the two SDI treatments were 51 and $81 \mathrm{~mm}$ less than the surface treatment, respectively. The higher soil evaporation for the surface treatment was reported to have occurred during the partial cover period. From their work, Evett et al. (2000) estimated that water savings of up to $10 \%$ of seasonal precipitation and irrigation could be achieved using $0.3 \mathrm{~m}$ deep SDI emitters. Blaine Hanson of the Univ. of California, Davis Dept. of LAWR indicates similar data and thoughts with processing tomato research near Five Points, Calif. (Blaine Hanson, personal communication, February 2001).

Ayars et al. reviewed 15 years of research from the USDAARS Water Management Research Laboratory, Fresno, Calif. Cited is Phene et al., who reported that with SDI $E$ was minimal, while $T$ increased. The high $T$ with the SDI systems was postulated to improve evaporative cooling of the crop canopy and to increase stomatal opening and photosynthesis. Evaporation from winter rains and from preirrigations by sprinkler or furrows and evaporation from a wet seedbed for establishing a plant stand were not discussed.

The trend among California's growers of lettuce, broccoli, cauliflower, peppers, and other similar crops is to move away from SDI and to surface-retrievable drip systems because of the inherent difficulties in managing SDI in many situations. Management problems and surface wetting with SDI on orchards have been frequently observed (Burt and Styles 1999).

Surface Drip/Micro. Dasberg (1995) found that sprinkler irrigations and micro irrigation that resulted in similar soil surface wetting resulted in similar amounts of the soil evaporation component of ET.

Burt and Styles (1999) and Burt (2000) note that some types of drip/micro system conditions will create at least as much, and probably more, soil evaporation than will occur under furrow irrigation. The vast majority of drip/micro systems are above ground, and the wetted areas may be quite large with some crops and emitter designs. Those wet soil surface regions are almost continuously wet, contributing to a high soil evaporation loss. This was also noted by Bresler (1975) and Meshkat et al. (2000). For about 15 years, Westlands Water District in the central San Joaquin Valley of California has collected district data that indicates $10-15 \%$ higher ET, part of which is $E$, for drip on almonds, as opposed to other irrigation methods (Westlands Water District 1993).

Simulations using the FAO-56 method (Burt et al. 2002) showed that the evaporation losses under drip/micro can be considerable and depend upon the type of drip/micro system used, the soil type, and the percent soil surface wetted area. Some of the simulated results are shown in Fig. 9. 


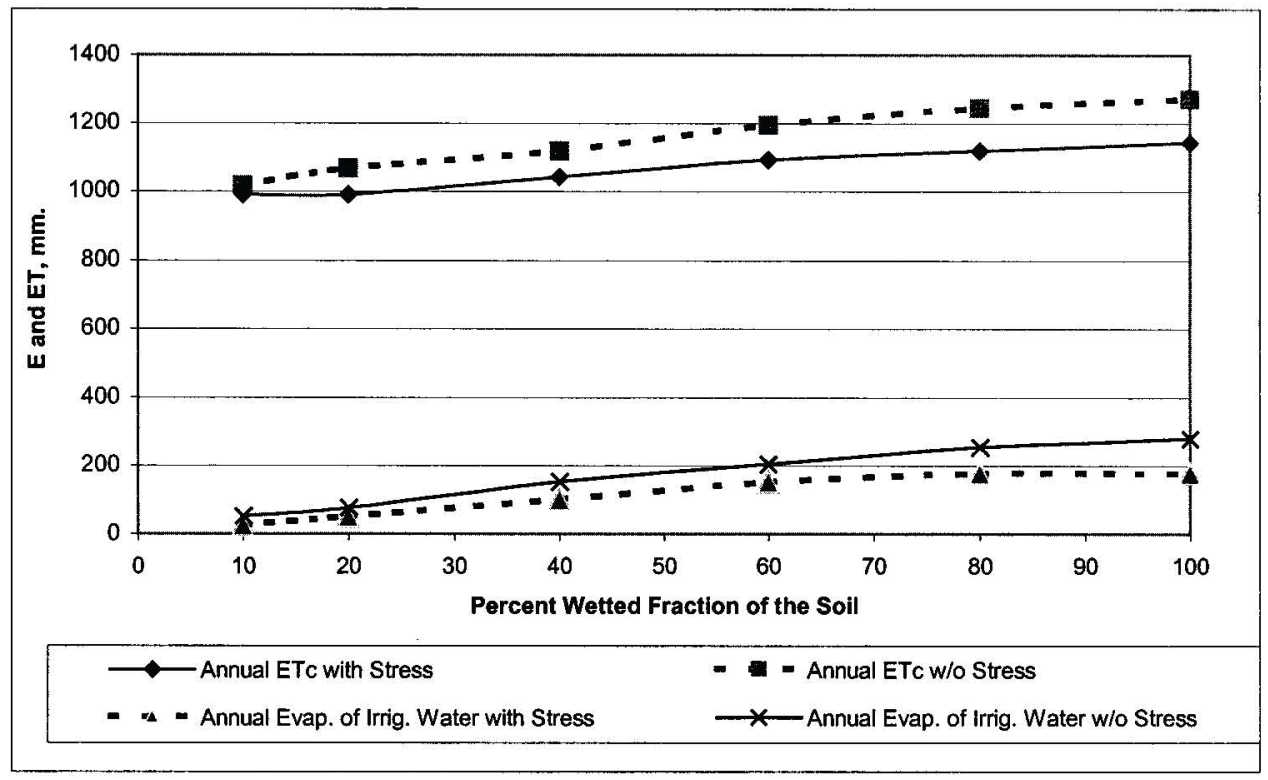

Fig. 9. Crop evapotranspiration and evaporation as the fraction of wetted area. Stressed and nonstressed almond trees irrigated with drip or microsprayers on the western side of the San Joaquin Valley of California. Other than crop stress and soil wetted fraction, the same crop parameters used in the overall study were used to do this comparison. Adjustments for bare spots and decreased vigor were not taken into account [derived from Burt et al. (2002)].

\section{Evaporation from Plant Surfaces}

\section{Wet Foliage Evaporation Observations and Discussion}

\section{Cupid Model}

One of the more thorough models for simulating the water and energy budget during an irrigation cycle is the Cupid model (Norman 1982; Norman's Cupid Web site: http://www.soils.wisc.edu/ soils/cupid.html). Cupid is a comprehensive soil-plantatmosphere model that uses inputs of leaf physiological characteristics (photosynthesis, stomatal conductance, and respiration), canopy architecture, and soil characteristics (heat and water properties) with boundary conditions at the bottom of the root zone and above the canopy. It can be used to predict water budgets of irrigated crops, water-use efficiency, canopy energy budgets, and leaf wetness duration. The thorough nature (meaning that a tremendous number of constants and physical parameters are needed) of the model makes it too complex for a broad regional study of evaporation. However, previous comparisons of measured and Cupid simulated water balances offer insight into the impact of evaporation from wet foliage.

An example for a fine sandy loam/silt loam soil was presented by Norman and Campbell (1983). Water budget measurements for an 8-day period in 1981 with a center pivot on corn in Garden City, Kan. were compared to a Cupid simulation of the budget (Table 13). The environmental conditions for the period are listed in Table 14. The specifics of the sprinklers used, spacing, irrigation rate, and irrigation timing were not identified. Therefore, unfortunately, it is almost impossible to use these numbers in a practical application because each of these factors could influence the results by $100 \%$ or more.

The prediction ability of the Cupid model is validated by the similarity between the measured and simulated water storage change and water input (Table 13). The balance of the water went to other components of ET, and the Cupid model used detailed energy balances to partition the ET components with time (Fig. 10 and Table 15).

The key points are

1. Daily transpiration was reduced when interception evaporation occurred.

2. The specific values of the percentage of evaporation are non-

Table 13. Comparison of Cumulative Corn Crop Water Budget from Cupid with Field Measurements During 8-Day Measurement Period for Pivot-Irrigated Corn in Garden City, Kan. [Reprinted from Norman and Campbell (1983) with Permission from Elsevier]

\begin{tabular}{lcccc}
\hline & & \multicolumn{3}{c}{ Measurements } \\
\cline { 3 - 5 } \multicolumn{1}{c}{ Component } & $\begin{array}{c}\text { Model } \\
(\mathrm{mm})\end{array}$ & $\begin{array}{c}\text { Mean } \\
(\mathrm{mm})\end{array}$ & $\begin{array}{c}\mathrm{SD}^{\mathrm{a}} \\
(\mathrm{mm})\end{array}$ & $\begin{array}{c}\text { Number of } \\
\text { observations }\end{array}$ \\
\hline Precipitation (input) & 79.1 & 79.1 & 2 & 12 \\
Total evapotranspiration & 49.0 & & & \\
$\quad$ Transpiration & 27.2 & & & \\
$\quad$ Soil evaporation & 18.2 & & & 20 \\
$\quad$ Interception loss & 3.8 & $\left(5.6^{\mathrm{b}}\right)$ & & \\
Net infiltration & 57.3 & & & \\
$\quad$ Stem flow & 36.9 & 27.9 & 3 & \\
$\quad$ Throughfall & 38.3 & 36.7 & 15 & \\
Drainage & 0.2 & & & \\
Storage & & & & \\
$\quad$ Initial & 280 & 282 & & \\
$\quad$ Final & 309 & 317 & & \\
Hours leaf wetness & $58-64$ & & & \\
\hline
\end{tabular}

${ }^{\mathrm{a}} \mathrm{SD}$, standard deviation.

${ }^{\mathrm{b}}$ Interception from nighttime rainfall events was not included in the measurements so $2 \mathrm{~mm}$ were added to the measured value of $3.6 \mathrm{~mm}$. 
Table 14. Summary of Hourly Environmental Data During 8-Day Measurement Period for Pivot-Irrigated Corn in Garden City, Kan. [Reprinted from Norman and Campbell (1983) with Permission from Elsevier] ${ }^{\mathrm{a}}$

\begin{tabular}{|c|c|c|c|c|c|c|c|c|}
\hline \multirow[b]{2}{*}{ Day number } & \multicolumn{2}{|c|}{$\begin{array}{c}\text { Air temperature } \\
\left({ }^{\circ} \mathrm{C}\right)\end{array}$} & \multirow{2}{*}{$\begin{array}{l}\text { Air water } \\
\text { vapor } \\
\text { pressure } \\
\text { (mbar) }\end{array}$} & \multicolumn{2}{|c|}{$\begin{array}{l}\text { Relative humidity } \\
(\%)\end{array}$} & \multirow{2}{*}{$\begin{array}{l}\text { Average } \\
\text { wind } \\
\text { speed } \\
\left(\mathrm{m} / \mathrm{s}^{-1}\right)\end{array}$} & \multirow{2}{*}{$\begin{array}{c}\text { Solar } \\
\text { radiation } \\
\left(\mathrm{MJ} / \mathrm{m}^{-2} / \text { day }^{-1}\right)\end{array}$} & \multirow{2}{*}{$\begin{array}{c}\text { Precipitation (P), } \\
\text { irrigation (I) } \\
(\mathrm{mm})\end{array}$} \\
\hline & Maximum & Minimum & & Minimum & Maximum & & & \\
\hline 201 & 35.0 & 18.2 & 22.2 & 44 & 92 & 2.0 & 29.4 & 0 \\
\hline 202 & 37.5 & 21.2 & 23.2 & 39 & 85 & 3.1 & 29.4 & 0 \\
\hline 203 & 26.1 & 18.4 & 22.4 & 70 & 99 & 2.6 & 14.1 & 36.1 (I) \\
\hline 204 & 33.4 & 19.9 & 23.2 & 47 & 93 & 2.1 & 23.4 & 0 \\
\hline 205 & 34.5 & 22.3 & 22.4 & 42 & 84 & 2.5 & 19.1 & 0 \\
\hline 206 & 29.9 & 17.8 & 22.6 & 57 & 100 & 1.8 & 20.2 & $6.4(\mathrm{P})$ \\
\hline 207 & 25.5 & 19.8 & 23.9 & 77 & 100 & 2.2 & 15.1 & $36.6(\mathrm{P})$ \\
\hline 208 & 27.8 & 17.8 & 22.1 & 63 & 100 & 2.2 & 16.7 & 0 \\
\hline
\end{tabular}

${ }^{\mathrm{a}}$ The solar radiation units should be average $\mathrm{MJ} / \mathrm{m}^{-2} \mathrm{~h}^{-1}$ for the day.

transferable because of the lack of data related to machine speed and application depths per pass.

\section{Evaporation Based on Time of Water Application}

Considering the evapotranspiration for a single day allows one to evaluate the short-term interception evaporation effects. Norman and Campbell (1983) presented the ET partitioning of three possible irrigation cases for Day 202 (Note: Day 202 had clear skies). The three cases were as follows:

Case 1: No irrigation or rainfall occurred on or recently before Day 202, and, therefore, the soil surface is dry (Fig. 11).

Case 2: A $12 \mathrm{~mm}$ rain occurs late on Day 201. The result was that on Day 202 the soil surface was wet, and it appears that since there is no interception evaporation on that day, the leaves were assumed to be dry (Fig. 12).

Case 3: Irrigation of $36.1 \mathrm{~mm}$ by a pivot system on Day 202 occurred between 1400 and 1700 hours. The soil surface was dry prior to irrigation, and the leaves were wet during and for some time after the irrigation (Fig. 13).

The key points are

1. Total ET was increased when a sprinkler irrigation event occurred;

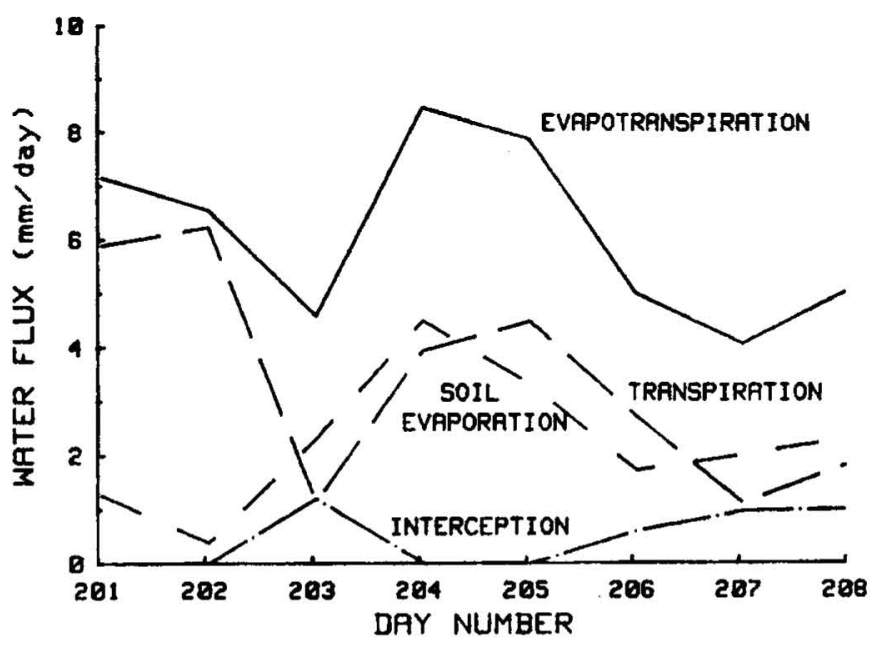

Fig. 10. Cupid simulated partitioning of Evapotranspiration during an 8-day measurement period for pivot-irrigated corn in Garden City, Kan. (Norman and Campbell 1983). Unfortunately, the lack of knowledge of the conditions makes this information nontransferable. Reprinted with permission.
2. Relative to the nonirrigation scenario, the previous evening irrigation scenario had less transpiration but more evaporation;

3. During the mid-day irrigation scenario, transpiration and the soil evaporation were markedly reduced during the period of time when the crop canopy was wet. Norman and Campbell (1983) noted that the transpiration is reduced by more than the fraction of the leaf area that is wet (0.2 in the simulation). The transpiration and soil evaporation reduction during this time were attributed to the canopy humidity increasing while intercepted water was evaporating. Hsiao (T. Hsiao, personal communication, 2000) noted that his studies indicate that the temporary cooling effect from evaporation of sprinkler irrigation droplets and the increase in local humidity may reduce soil $E$ and $T$ by 20 to $35 \%$ during irrigation.

The evapotranspiration for the above three cases was not integrated with time for a quantitative comparison of the impact of the different irrigation conditions and the interception evaporation. However, Tolk et al. (1995) made some conclusions about this issue. They made stem flow measurements of transpiration reductions for well-irrigated corn with impact sprinklers on a linear move system in Bushland, Tex. They reported $T$ "suppression due to evaporation of canopy-intercepted water and microclimatic modification resulted in net crop canopy-interception losses between 5 and $7 \%$ of the applied irrigation water." This percentage, of course, depends upon the application depth and frequency of irrigation. Net crop canopy-interception loss was defined in McNaughton (1981) as the difference between the $T$ from a nonirrigated area and the gross interception loss from an identical area that is irrigated. Tolk et al. (1995) also noted that "transpiration recovery to near pre-irrigation levels was rapid, with additional transpiration suppression of $1-3 \%$ occurring only on days with high solar radiation."

\section{Evaporation Based on Method of Water Application}

A similar set of cases was presented by Thompson (1997), and provided a daily integration of ET and the partitioning of $E$ and $T$ as simulated with Cupid-DPEVAP (Cupid with a droplet evaporation component). This paper evaluated ET for linear-move irrigated corn on Pullman clay loam soil in Bushland, Tex. on July 11, 1989 (Day 192). The daily average wind speed was $6.6 \mathrm{~m} \cdot \mathrm{s}^{-1}$ and the daily average solar radiation was $26.2 \mathrm{MJ} \cdot \mathrm{h}^{-1} \mathrm{~m}^{2}$. The scenarios for Day 192 (all irrigation times started at noon) are listed below, and the results are summarized in Fig. 14.

Case 1: $23 \mathrm{~mm}$ of irrigation was applied with a linear-move irrigation system using spray heads with $3.2 \mathrm{~mm}$ nozzles, $1.52 \mathrm{~m}$ 
Table 15. Example of Detailed Crop Canopy and Soil Surface Energy Balance Components for Specific Hours on Day 202 for Several Possible Wind and Solar Radiation Levels for Pivot-Irrigated Corn in Garden City, Kan. [Reprinted from Norman and Campbell (1983) with Permission from Elsevier]

\begin{tabular}{|c|c|c|c|c|c|c|c|c|c|c|c|c|c|}
\hline \multirow[b]{2}{*}{$\begin{array}{l}\text { Surface } \\
\text { characteristic }\end{array}$} & \multicolumn{7}{|c|}{ Within canopy } & \multicolumn{6}{|c|}{ Soil surface } \\
\hline & $\begin{array}{c}\text { NIR } \\
\left(\mathrm{W} / \mathrm{m}^{-2}\right)\end{array}$ & $\begin{array}{c}\mathrm{TL} \\
\left(\mathrm{W} / \mathrm{m}^{-2}\right)\end{array}$ & $\begin{array}{c}\text { SHL } \\
\left(\mathrm{W} / \mathrm{m}^{-2}\right)\end{array}$ & $\begin{array}{c}\text { IHS } \\
\left(\mathrm{W} / \mathrm{m}^{-2}\right)\end{array}$ & $\begin{array}{l}T_{c p y} \\
\left({ }^{\circ} \mathrm{C}\right)\end{array}$ & $\begin{array}{l}T_{\text {air }} \\
\left({ }^{\circ} \mathrm{C}\right)\end{array}$ & $\begin{array}{c}\overline{e_{\text {air }}} \\
\text { (mbar) }\end{array}$ & $\begin{array}{c}\text { NIR } \\
\left(\mathrm{W} / \mathrm{m}^{-2}\right)\end{array}$ & $\begin{array}{c}\text { EL } \\
\left(\mathrm{W} / \mathrm{m}^{-2}\right)\end{array}$ & $\begin{array}{c}\text { SHL } \\
\left(\mathrm{W} / \mathrm{m}^{-2}\right)\end{array}$ & $\begin{array}{c}\text { IHS } \\
\left(\mathrm{W} / \mathrm{m}^{-2}\right)\end{array}$ & $\begin{array}{l}T_{s f c} \\
\left({ }^{\circ} \mathrm{C}\right)\end{array}$ & $\begin{array}{c}\mathrm{RH} \\
\text { (lowest } \\
\text { canopy } \\
\text { layer) }\end{array}$ \\
\hline \multicolumn{14}{|c|}{ Hour $14\left(\right.$ wind speed $=3.1 \mathrm{~m} / \mathrm{s}^{-1}$; solar radiation $\left.=984 \mathrm{~W} / \mathrm{m}^{-2}\right)$} \\
\hline Dry & 499 & 507 & -11 & 3 & 36.3 & 36.5 & 27.5 & 251 & 24 & 88 & 141 & 38.2 & 0.42 \\
\hline Wet & 478 & 425 & 51 & 2 & 34.4 & 34.0 & 30.0 & 296 & 399 & -211 & 110 & 28.0 & 0.94 \\
\hline \multicolumn{14}{|c|}{ Hour $15\left(\right.$ wind speed $=1.6 \mathrm{~m} / \mathrm{s}^{-1} ;$ solar radiation $\left.=984 \mathrm{~W} / \mathrm{m}^{-2}\right)$} \\
\hline Dry & 494 & 438 & 66 & 4 & 39.7 & 38.5 & 27.2 & 238 & 28 & 64 & 145 & 40.1 & 0.38 \\
\hline Wet & 471 & 382 & 85 & 4 & 37.1 & 36.0 & 33.0 & 280 & 267 & -132 & 146 & 30.0 & 0.94 \\
\hline \multicolumn{14}{|c|}{ Hour $15\left(\right.$ wind speed $=0.5 \mathrm{~m} / \mathrm{s}^{-1}$; solar radiation $\left.=984 \mathrm{~W} / \mathrm{m}^{-2}\right)$} \\
\hline Dry & 441 & 302 & 135 & 7 & 44.8 & 38.5 & 27.2 & 253 & 29 & 41 & 180 & 42.0 & 0.36 \\
\hline Wet & 421 & 293 & 123 & 6 & 41.2 & 37.1 & 31.0 & 299 & 255 & -111 & 154 & 30.2 & 0.90 \\
\hline \multicolumn{14}{|c|}{ Hour $14\left(\right.$ wind speed $=3.1 \mathrm{~m} / \mathrm{s}^{-1}$; solar radiation $\left.=325 \mathrm{~W} / \mathrm{m}^{-2}\right)$} \\
\hline Dry & 197 & 309 & -94 & 2 & 33.4 & 34.5 & 26.6 & 60 & 18 & -47 & 90 & 33.1 & 0.53 \\
\hline Wet & 179 & 241 & -48 & 2 & 31.8 & 32.7 & 28.3 & 89 & 245 & -225 & 71 & 25.8 & 0.95 \\
\hline \multicolumn{14}{|c|}{ Hour $15\left(\right.$ wind speed $=1.7 \mathrm{~m} / \mathrm{s}^{-1} ;$ solar radiation $\left.=325 \mathrm{~W} / \mathrm{m}^{-2}\right)$} \\
\hline Dry & 204 & 287 & -65 & 2 & 34.0 & 35.2 & 29.2 & 60 & 5 & -25 & 81 & 33.5 & 0.57 \\
\hline Wet & 186 & 225 & -25 & 2 & 32.5 & 33.4 & 30.8 & 88 & 107 & -108 & 88 & 26.9 & 0.97 \\
\hline \multicolumn{14}{|c|}{ Hour $15\left(\right.$ wind speed $=0.5 \mathrm{~m} / \mathrm{s}^{-1} ;$ solar radiation $\left.=325 \mathrm{~W} / \mathrm{m}^{-2}\right)$} \\
\hline Dry & 198 & 243 & -29 & 2 & 34.3 & 35.5 & 31.4 & 64 & 0 & -17 & 81 & 33.1 & 0.62 \\
\hline Wet & 179 & 214 & -21 & 2 & 33.4 & 34.4 & 31.9 & 90 & 28 & -37 & 100 & 27.3 & 0.99 \\
\hline
\end{tabular}

Abbreviations: NIR, net incoming radiation; TL, transpiration loss; EL, evaporation loss; SHL, sensible heat loss; IHS, increase in heat storage; RH, relative humidity.

spacing, $1.5 \mathrm{~m}$ above the ground, a discharge rate $=6.4 \mathrm{~L} \cdot \mathrm{min}^{-1} \mathrm{~m}^{-1}$, and a water pressure of $234 \mathrm{kPa}$.

Case 2: $27 \mathrm{~mm}$ of irrigation was applied with a linear-move irrigation system using impact sprinklers with $6.5 \mathrm{~mm}$ nozzles, $6.1 \mathrm{~m}$ spacing, $4.3 \mathrm{~m}$ above the ground, a discharge rate $=6.0 \mathrm{~L} \cdot \mathrm{min}^{-1} \mathrm{~m}^{-1}$, and a water pressure of $230 \mathrm{kPa}$.

Case 3: No irrigation or rainfall and the soil surface was dry. The key points are

1. Predicted spray droplet evaporation for the day for both irrigation scenarios was $0.05 \mathrm{~mm}$, or $0.2 \%$ of the application depth.

2. The spray and impact head irrigations resulted in 23 and $29 \%$

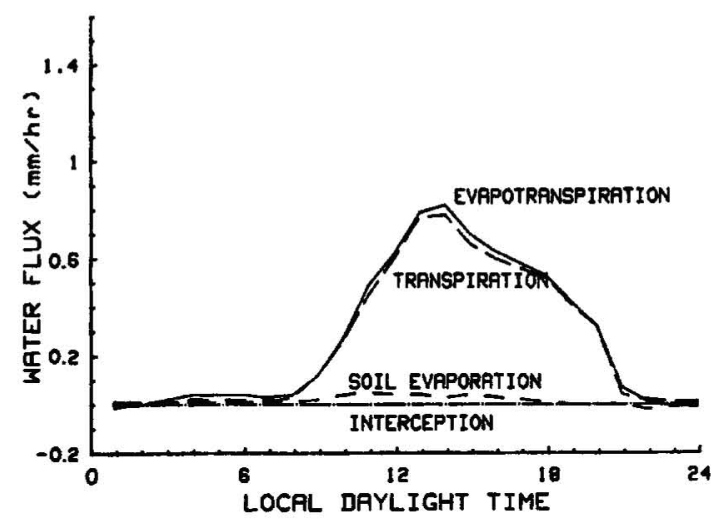

Fig. 11. Diurnal water budget for Julian Day 202 with no irrigation or rainfall and a dry soil surface for pivot-irrigated corn in Garden City, Kan. (Norman and Campbell 1983). Reprinted with permission. more total ET for the day, respectively, than the non-irrigated scenario.

3. Compared to the nonirrigation scenario, the irrigation scenarios had less transpiration.

4. In both the Garden City, Kan. and the Bushland, Tex. evaluations, wet foliage evaporation for the clear daytime simulated irrigation scenarios is less than soil evaporation.

5. Certainly, the wet foliage evaporation contribution to the effective loss of applied water will depend on the irrigation practices and environmental conditions at the time of the irrigation event. For example, ITRC engineers have wit-

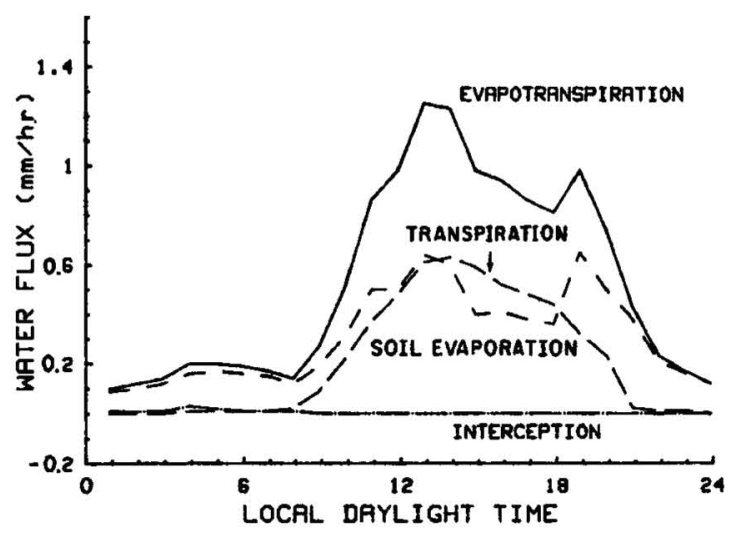

Fig. 12. Diurnal water budget for Day 202 assuming $12 \mathrm{~mm}$ of rain late on Day 201 wet the soil surface, but the leaves were dry on Day 202. Pivot-irrigated corn in Garden City, Kan. (Norman and Campbell 1983). Reprinted with permission. 


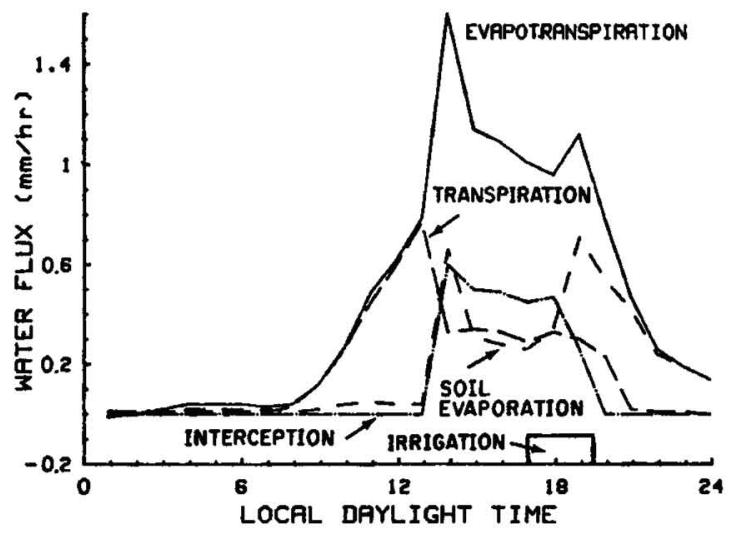

Fig. 13. Diurnal water budget for Day 202 assuming $36.1 \mathrm{~mm}$ of irrigation water was applied by pivot between 1400 and 1700 hours on Day 202. The soil surface was dry prior to the irrigation. Pivot irrigated corn in Garden City, Kan. (Norman and Campbell 1983). Note: the irrigation on the graph is in the wrong location on the time axis. Reprinted with permission.

nessed how frequent short duration irrigations with centerpivots can result in nearly all of the applied water being lost to evaporation before having an opportunity to penetrate into the soil. Norman (J. M. Norman, personal communication, 2001) confirmed this observation by saying that the advective forces of a dry crop/soil environment in front of centerpivots and linear-move irrigation systems coupled with high winds and sunny conditions can result in tremendous evaporative forces on the order of $1 \mathrm{~mm} / \mathrm{h}$ or more. He added that this evaporation loss, combined with the eventual evaporation of 1 to $4 \mathrm{~mm}$ of water stored on the leaves and about $5 \mathrm{~mm}$ of nonbeneficial loss from the soil surface, means that an application of less than 5 to $10 \mathrm{~mm}$ can almost be completely lost to evaporation.

6. Table 16 presents an estimate of the amount of time a typical leaf is wet during the daytime hours for the irrigation systems that wet the crop canopy.

7. It seems clear from Fig. 14 that on the day of an irrigation

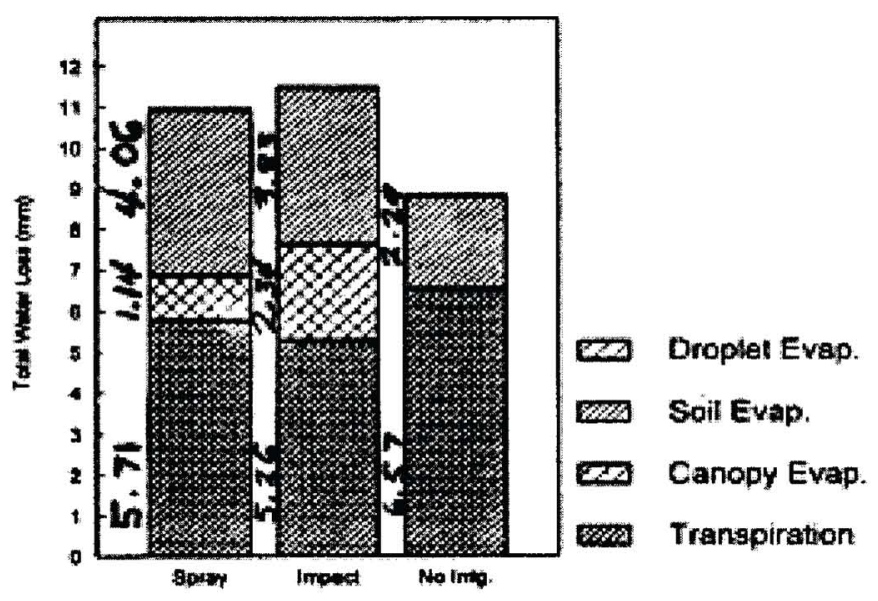

Fig. 14. Cumulative water loss budget for three simulated water application cases for July 11, 1989. Linear-move irrigated corn in Bushland, Tex. (Thompson 1997). Reprinted with permission from the American Society of Agricultural Engineers.
ET increases. This increase is due to the introduction of readily evaporable water to soil and leaves.

8. Allen and Pruitt (1996) identified that when a crop canopy is wet ET may be $60 \%$ greater than when it is dry. By comparing the Cupid simulations for the three irrigation scenarios (Figs. 10-12) for Garden City, Kan., the ET rate increase, when the canopy is wet relative to when it is dry at 1600 hours, is

9. $70 \%(1.1$ versus $0.65 \mathrm{~mm} / \mathrm{h})$ when the soil is dry.

10. $22 \%(1.1$ versus $0.9 \mathrm{~mm} / \mathrm{h})$ when the soil is wet.

11. No studies were found that described the amount of ET increase when the leaves are wet for an entire daytime period from irrigation. The following comments about this are offered:

a. The period of time when the canopy is wet during the pivot irrigation in Fig. 12 offers some insight into the long period wetting case. When the soil becomes wet shortly after the irrigation begins, the Cupid model predicts that the soil evaporation sharply increases and the transpiration sharply decreases.

b. After the foliage wets to its maximum storage capacity and the canopy environment is humidified, the soil evaporation reduces.

c. A low resistance to evaporation occurs for virtually all of a $12-\mathrm{h}$ daytime irrigation that uses solid-set sprinklers. The resulting daily ET should approach the potential ET for the day, with evaporation from wet foliage being the dominant component of that day's ET. As in Fig. 13, it would be of interest to compare the increase in daily ET for a solid-set irrigation that wets the leaves for all of the daylight hours to the ET that would occur without that irrigation.

d. Had the solid-set irrigation identified in the previous point been applied at night, there would have been little energy to evaporate the readily evaporable water on the leaves. It seems apparent then that the amount of $24 \mathrm{~h}$ ET (starting at the beginning of an irrigation event) for the nighttime irrigation event would be less than the $24 \mathrm{~h}$ ET for the daytime irrigation event. Because the nighttime irrigation has a small foliage evaporation component, the soil will receive more application than it will for the same irrigation amount applied in the daytime.

\section{Other $E$ and T Partitioning}

Lascano et al. (1994) reported a 100-day $E$ reduction of $39 \%$ for a stubble/no-till treatment verses a conventional tillage treatment for cotton on an Olton sandy clay loam soil in Lubbock, Tex. (Table 10). That paper also evaluated the cumulative 100-day evapotranspiration partitioning for the two treatments where $E$ was measured with microlysimeters. The model ENWATBAL (Lascano et al. 1987; Evett and Lascano 1993; Qiu et al. 1999) on-site weather measurements and neutron probe measurements were used to determine the energy and water balance in the system. Measured and simulated $E$ s were well matched, and $T$ was determined by taking the difference between simulated ET and $E$. The rainfall and furrow irrigation total was $325 \mathrm{~mm}$. Both treatments had the same 100-day cumulative ET (325 mm); however, the partitioning of $E$ and $T$ differed between them (Table 17).

The stubble/no-till treatment had 39\% more transpiration than the conventional tillage treatment, and this resulted in $35 \%$ more cotton lint yield than the conventional treatment ( 830 versus $613 \mathrm{~kg} \cdot \mathrm{ha}^{-1}$ ).

As described in the section on microlysimeters, the true mea- 
Table 16. Estimates of the Percentage of Time During a Growing Season (with 100 Days of Canopy) That Foliage Evaporation Occurs for Sprinkler Irrigation Systems [Derived from Burt et al. (2002)]

\begin{tabular}{|c|c|c|c|c|c|}
\hline $\begin{array}{l}\text { Irrigation } \\
\text { method }^{\mathrm{a}}\end{array}$ & $\begin{array}{c}\text { Percentage of } \\
\text { California irrigated } \\
\text { agricultural } \\
\text { land area }{ }^{\mathrm{a}}\end{array}$ & $\begin{array}{l}\text { Irrigation } \\
\text { intervals }\end{array}$ & $\begin{array}{l}\text { Leaf water contact } \\
\text { assumptions }\end{array}$ & $\begin{array}{l}\text { Estimated equivalent } \\
\text { daytime hours that } \\
\text { leaves are wet } \\
\text { (hours) }^{\mathrm{d}}\end{array}$ & $\begin{array}{c}\text { Estimated percentage } \\
\text { of } 1,200 \text { day time } \\
\text { hours that leaves } \\
\text { are wet }\end{array}$ \\
\hline $\begin{array}{l}\text { Center pivots, } \\
\text { linear move, } \\
\text { and traveler }\end{array}$ & $\begin{array}{l}\text { Combined } \\
\text { area }<5^{b}\end{array}$ & $\begin{array}{l}50 \text { passes per } \\
\text { season at } 2 \text { day } \\
\text { interval }\end{array}$ & $\begin{array}{l}\text { Typical leaf in } \\
\text { contact with } \\
\text { irrigation water } \\
\text { for } 15 \text { min and } \\
\text { being dry after } 2 \mathrm{~h} \\
\text { for a } \\
\text { daytime irrigation }^{\mathrm{c}}\end{array}$ & 112 & 9 \\
\hline $\begin{array}{l}\text { Hand move, } \\
\text { side roll/ } \\
\text { Wheel Line }\end{array}$ & $20,1.4$ & $\begin{array}{l}\text { Six irrigations } \\
\text { per season with } \\
24 \mathrm{~h} \\
\text { between moves }\end{array}$ & $\begin{array}{l}\text { Typical leaf in } \\
\text { contact with } \\
\text { irrigation water } \\
\text { for a two-move } \\
\text { period }+2 \mathrm{~h}\end{array}$ & 156 & 13 \\
\hline $\begin{array}{l}\text { Solid-set } \\
\text { sprinklers }\end{array}$ & 3 & $\begin{array}{l}15 \text { irrigations } \\
\text { with } 6 \mathrm{~h} \\
\text { sets }\end{array}$ & $\begin{array}{l}\text { Typical leaf in } \\
\text { contact with } \\
\text { irrigation water } \\
\text { for } 6+2 \mathrm{~h}\end{array}$ & 120 & 10 \\
\hline
\end{tabular}

aFrom "1998 Annual" (1999). The various irrigation systems were broken into the following three categories: sprinkler, gravity, and low flow. The total 1998 California irrigated acreage was identified as 9.6 million acres.

${ }^{b}$ The 1998 Annual Irrigation Survey reports the percentage of travelers to be about $5 \%$ in California. The correct number is probably closer to $1 \%$.

${ }^{\mathrm{c}}$ Thompson (1997) observed that the water on the corn leaves dried within 30 min after a daytime center-pivot irrigation (average daily wind $=6.6 \mathrm{~m} / \mathrm{s}^{-1}$ and average solar radiation was $26.2 \mathrm{MJ} / \mathrm{h}^{-1} \mathrm{~m}^{-2}$ for the day in Bushland, Tex.). However, for many crops more time is needed to dry the leaves. Two hours was estimated as an average during an average time of daylight.

${ }^{\mathrm{d}}$ It is assumed that no appreciable evaporation from the canopy occurs at night.

surement of $E$ before crop development in the CT treatment may have been low if the microlysimeters were in fact made of aluminum as is postulated. For the NT treatment, early measured $E$ may have also been low, but would probably not have been impacted as significantly as the CT treatment because there would have been shading from the standing stubble. Effectively then, it is possible that the true $E$ reduction from the NT treatment was somewhat larger than the $39 \%$ listed in Table 17. Further, the percentage of transpiration increase between the CT and NT treatments may have been somewhat larger than the previously identified $36 \%$.

Recall that Fig. 14 by Thompson et al. (1997) demonstrated that even with the short irrigation water contact time with a crop that is associated with a linear-move irrigation system, daily $T$ is suppressed relative to $T$ where an irrigation event does not occur. Tolk et al. (1995) measured similar suppression with stem flow measurements and attributed the reduction to evaporation of canopy-intercepted water and microclimatic modification. Total ET for the day increased for the irrigated relative to the nonirri-

Table 17. One Hundred Day Soil Evaporation and Transpiration Reduction Using No-Till and Planting in Standing Stubble for Olton Sandy Clay Loam with Limited Irrigation [Derived from Lascano et al. (1994)]

\begin{tabular}{|c|c|c|c|c|}
\hline Treatment & $\begin{array}{c}\text { 100-day } E \\
(\mathrm{~mm})\end{array}$ & $\begin{array}{c}\text { Percentage } E \\
\text { reduction }\end{array}$ & $\begin{array}{c}\text { 100-day } T \\
(\mathrm{~mm})\end{array}$ & $\begin{array}{c}\text { Percentage } 7 \\
\text { reduction }\end{array}$ \\
\hline $\begin{array}{l}L^{\mathrm{a}}, \mathrm{CT}^{\mathrm{b}}, \text { cotton } \\
\text { and no mulch }\end{array}$ & 162 & - & 162 & - \\
\hline $\begin{array}{l}L, \mathrm{NT}^{\mathrm{c}} \text {, cotton and } \\
\text { standing stubble }\end{array}$ & 100 & $39 \%$ & 225 & $39 \%$ \\
\hline
\end{tabular}

gated scenarios due to the introduction of readily evaporable water to the soil and the low resistance to evaporation of free water on the leaves.

Howell et al. (1991) reported the daily transpiration amounts throughout the day of a linear move irrigation of corn in Bushland, Tex. using impact sprinklers. Total transpiration was estimated from the product of the mean measured plant transpiration and the mean lysimeter plant density, where the $T$ from three to five individual plants was measured with sap flux gauges. They found that morning $T$ before the irrigation was about $70 \%$ of the ET; $T$ then dropped to about $10 \%$ of the ET during the irrigation and remained low until the foliage dried, after which $T$ returned to about $70 \%$ of ET. For a $25 \mathrm{~mm}$ application, they concluded that the application method (impact sprinklers, spray nozzles, and low energy precision applicators (LEPA)) did not have a big effect on the crop ET after the irrigation. Further, they found that following the canopy drying ET rates approach those for nonirrigated canopies if the nonirrigated crop is not under significant soil water deficit. Again, the somewhat larger daily ET shown in Fig. 14 for the irrigated versus the nonirrigated crop is the result of readily evaporable water in the soil and the low resistance to evaporation of free water on the leaves during, and for some period after, the irrigation event.

\section{Leaf Water Storage and Potential Applications for Coupled Energy and Water Balance Methods}

In the previous section, reference was made to leaf storage of irrigated water and rain. For reference purposes, specifics about leaf water storage identified in the literature will now be discussed. Little information was located on foliage evaporation for agriculture.

Lamm and Manges (2000) used a water balance equation with 
measurements of stemflow, throughfall, and irrigation application to estimate the leaf water storage for fully developed corn canopies

$$
I_{a}=S G-\left(S_{a}+T_{a}\right)
$$

where $I_{a}=$ portion of the application depth that is intercepted by and stored on the crop canopy ( $\mathrm{mm}) ; S G=$ application depth (mm); $S_{a}=$ portion of the application depth that is transported off of the crop by stem flow $(\mathrm{mm})$; and $T_{a}=$ portion of the application depth that falls through the crop to the soil surface $(\mathrm{mm})$.

Lamm and Manges (2000) collected rather extensive measurements for 23 different irrigation/precipitation events during calm predawn conditions with different sprinkler types and crop spacing. The predawn measurements allowed them to assume that loss from evaporation was negligible. The average $I_{a}$ value was $1.8 \mathrm{~mm}$. The standard deviation about this mean was $2.0 \mathrm{~mm}$, a rather large value that demonstrates the potential experimental error associated with this method. For three nominal plant spacings of $0.2,0.3$, and $0.41 \mathrm{~m}$, the average $S_{a}$ values for the three sprinkler systems evaluated were 53,46 , and $38 \%$, respectively, and the average $T_{a}$ values were 44,47 , and $50 \%$, respectively.

Allen and Pruitt (1996) identified the following maximum canopy storage equation used for forests:

$$
S=0.2 \mathrm{LAI}
$$

where $S==$ amount of water stored on the foliage per $\mathrm{m}^{2}$ of land surface $(\mathrm{mm})$; The coefficient $(0.2)=$ maximum canopy interception storage per unit one-sided leaf area $(\mathrm{mm})$; and $\mathrm{LAI}=$ onesided area of leaves per unit ground surface area (Norman and Campbell 1998).

Norman (J. M. Norman, personal communication, 2001) stated that for agricultural crops the coefficient typically used in Cupid is 0.15 . This has been used for simulations for prairie grass, rangeland, soybeans, corn, potatoes, black spruce, and desert shrub (Norman and Campbell 1983; Wilson et al. 1999; Anderson et al. 2000). He also noted that the coefficient is not static, resulting in $S$ varying from 0.15 to $1 \mathrm{~mm}$. Some of the dynamics pertain to timing and leaf properties. Early in an irrigation event, leaf water tends to be stored as droplets, while later the droplets coalesce into films. The films represent the low value of $S$ and the droplets the high value. From lysimeter studies in Bushland, Tex., Howell et al. (1991) estimated that for corn $S$ may be $1 \mathrm{~mm}$ and that the evaporation rate from the wet foliage during the irrigation approaches 0.5 to $1 \mathrm{~mm} / \mathrm{h}$.

Another component of leaf evaporation is the fraction of the leaves that are currently storing the water on the leaves. (This is not to be confused with the coefficient in the maximum canopy storage equation above.) When the leaves have a maximum amount of water stored, as defined in Eq. (6), canopy evaporation takes place only from the fraction of leaf area wetting. The remainder of the leaf area continues to transpire (see Fig. 13), although Norman and Campbell (1983) note that the transpiration is reduced by more than the 0.2 fraction of leaf area wetting they used in Cupid. They attribute the larger transpiration reduction to the humidification of the plant/soil environment. The typical value of the fraction of the leaves storing the leaf water used in Cupid and ALEX is 0.2. However, Norman (J. M. Norman, personal communication, 2001) said that in work he has been involved with this value has varied from 0.1 to 0.9 .

Norman and Campbell (1983) identified the following plant characteristics as inputs to the Cupid model:

- LAI;

- Plant height;
- Height of the lowest leaves;

- Height of the most dense region of the canopy;

- Row and plant spacing;

- Mean leaf size for the canopy;

- Leaf angle distribution;

- Foliage spectral properties;

- Stomatal conductance versus light and temperature;

- Leaf water potential;

- Plant hydraulic resistance; and

- Root length density distribution.

All of these characteristics impact the dynamics of the water balances for the canopy system layers, which are computed using energy balances. Many of these characteristics are used to identify how much solar radiation reaches a given layer in the canopy. Many are used to calculate the probability that a drop will reach the ground without collision, and the probability of droplets falling from leaves impacting leaves in lower layers. The characteristics are also used to calculate the amount of stem flow of intercepted water. (It is assumed that half of the intercepted water experiences stem flow.)

The crop/soil environment is highly dynamic, and accurate field measurements of the component processes are difficult to obtain in enough detail and over a long enough period of time to answer focused questions. A good deal of work has been done to validate highly integrated layered models such as Cupid. The result is a tool that if carefully used can help evaluate many possible scenarios of focused questions, such as how much seasonal reduction in $E$ can be expected if a solid-set irrigation system applies water at night instead of in the day, and how does this timing impact other components in the system.

\section{Sprinkler Droplet (in Air) Evaporation Loss}

\section{Measured and Simulated Spray Loss}

Using the one-dimensional (1D) mass and heat transfer CupidDPEVAP model, Thompson (1993b, 1997) demonstrated that droplet evaporation for an irrigation event with solid-set impact sprinklers is a very small component of applied water loss. In a Nebraska study, the measured loss was slightly negative ( $-0.12 \mathrm{~mm}$ or $-0.3 \%$ of the application depth). It was postulated that this was caused by the cold solid-set sprinkler spray condensing water from the warmer air. We speculate that it could also fall within measurement errors. The total ET for the day was $9 \mathrm{~mm}$, and the total irrigation depth was $38.7 \mathrm{~mm}$. In the Bushland, Tex. study, the spray loss was 0.05 and $0.06 \mathrm{~mm}(0.2 \%$ each) for the impact sprinkler and spray nozzle treatments, respectively. The application depths for the two treatments were 23 and $27 \mathrm{~mm}$, respectively. Thompson (1993a) states that in general, of the total amount of applied water, loss from sprinkler droplets traveling through the air is small (less than $2 \%$ ), with the main losses arising from wet canopy and soil evaporation.

One should note that the 1D nature of the Cupid-DPEVAP model limits its application to field locations where advection is not a major system variable. For example, it would more effectively model the energy and mass budget of the soil-plantatmosphere system in the middle of a field than near the field edge.

It is reasonable to assume that spray loss from center-pivot or wheel-line systems may be due more to the advective forces of the dry environment they move toward. However, Howell et al. (1991) stated that for linear-move irrigation systems in Bushland, 
Tex., their lysimeter based study results indicated that spray droplet evaporation may be on the order of 1 to $3 \%$ for spray nozzles and impact sprinklers, respectively (Senninger $360^{\circ}$ spray nozzles with medium-grooved spray plates with $1.5 \mathrm{~m}$ spacing, a mean elevation of $1.5 \mathrm{~m}$ above the ground, $240 \mathrm{kPa}$ at the inlet tower, $3.2 \mathrm{~mm}$ nozzle diameter, and an application rate of $6.4 \mathrm{~L} \cdot \mathrm{min}^{-1} \mathrm{~m}^{-1}$. Senninger $6^{\circ}$ impact sprinklers with $6 \mathrm{~m}$ spacing, a mean elevation of $4.3 \mathrm{~m}$, the same pressure, $6.7 \mathrm{~mm}$ nozzle diameter, and an application rate of $6 \mathrm{~L} \cdot \mathrm{min}^{-1} \mathrm{~m}^{-1}$ ).

A literature review by Howell et al. (1991) presented spray loss results from about 20 papers. Several of the papers demonstrated that spray evaporation was related to wind speed and vapor pressure deficit. The papers presented a wide range $(0.4$ to $45 \%$ ) of measured or estimated evaporation losses from a variety of irrigation systems. Below are some example results from these papers, without details:

1. Wiser et al. (1961) concluded that the spray evaporation rate would be similar to that of a free water surface and independent of application rate.

2. Seginer $(1970,1971,1973)$ proposed a resistance-type model to estimate spray evaporation losses that indicated spray losses would only be a few percent of the application rate.

3. Clark and Finley (1975) reported spray evaporation losses varying from 1 to almost $30 \%$ in Bushland, Tex. For wind speeds below $4.5 \mathrm{~m} \cdot \mathrm{s}^{-1}$, spray evaporation was correlated to vapor pressure and wind speed. For wind speeds above $4.5 \mathrm{~m} \cdot \mathrm{s}^{-1}$, the spray evaporation loss increased exponentially with wind speed.

4. Steiner et al. (1983) reported mean spray losses for a centerpivot sprinkler system of 12 to $16 \%$ for 2 years in Kansas, but found rather poor correlation between vapor pressure deficit, temperature, and wind speed.

Kincaid (D. C. Kincaid, personal communication, 2000) from USDA-ARS believes that mass and heat transfer models, such as those presented by Kincaid and Longley (1989) and Thompson (1993a), predict sprinkler evaporation more precisely (about 2\% of the applied water) than volumetric catch measurement collected in calm conditions (about $5 \%$ of the applied water). These observations come from tests he has conducted with linear-move irrigation systems in Kimberly, Id., using various brands and styles of rotator and plate heads. He identified several reasons for this discrepancy:

1. Catch measurements are prone to extra evaporation from their wetted side walls.

2. Catch devices receive increased energy exposure as compared to the surrounding soil.

3. Evaporation from the catch devices occurs before the amount of water caught can be measured.

To minimize measurement errors, Kincaid has begun using large area and volume catch devices, which he believes will reduce errors. These measurement errors are not factors when the irrigation is simulated with a model. However, although a model may bypass measurement errors, it will likely have its own limitations or bias in the mathematics it uses.

Using the difference in the electrical conductivity between the water supplying the irrigation and the captured irrigation water, Kohl et al. (1987) in Brookings, S.D. determined the spray loss was $0.5 \%$ for coarse serrated spray plates and $0.9 \%$ for smooth serrated spray plates. Approximately $40 \%$ of the spray loss from the tests occurred from water droplets that either evaporated or were carried as drift beyond the $60 \mathrm{~m}$ sampling zone from the sprinklers. This study was accomplished in the summer of 1985 using a line source with $360^{\circ}$ commercial sprinklers that were
$4 \mathrm{~m}$ above the soil surface at $2.29 \mathrm{~m}$ spacing. The nozzle size was $6.4 \mathrm{~mm}$, the pressure was $100 \mathrm{kPa}$, and the flow was $0.184 \mathrm{~L} / \mathrm{s} / \mathrm{m}$ of $22^{\circ} \mathrm{C}$ water supply. The average environmental conditions for the tests were: $26^{\circ} \mathrm{C}$ air temperature, $64 \%$ relative humidity, and $6.4 \mathrm{~m} / \mathrm{s}$ windspeed.

Results, without details, from other papers that used electrical conductivity to determine spray loss were reported by Mclean et al. (1994):

1. In California, George (1955) reported that a rotating sprinkler on a solid-set lateral had losses that ranged from 2-15\%. The results demonstrated a relationship between spray loss and relative humidity and showed that wind velocity was also a factor.

2. Hermsmeir (1973) reported that evaporation from stationary sprinklers could range from 0 to $50 \%$ over short periods. He noted that daytime evaporation in July and August in California's Imperial Valley is 3 to 4 times more than that at night. He reported that air temperature and rate of application are better factors for estimating sprinkler evaporation than wind speed or relative humidity.

3. In Nebraska, Yazar (1984) reported losses of 1.5-16.8\% of the total applied water from impact sprinklers. He found that both the wind velocity and the vapor pressure deficit had exponential relationships with spray loss.

The Center Pivot Design Manual (Allen et al. 2000) states that "wind drift and evaporation losses may be as little as a few percent when irrigating a crop with a full vegetative canopy in low winds. Under more common conditions, wind drift and evaporation losses range between 5 and $10 \%$. However, under very severe conditions, they can be considerably greater." Also offered is Fig. 6.8 by Keller and Bliesner (1990) as a "guide for estimating the effective fraction of applied water that reaches the soil-plant surface." The figure was developed for wheel-line, solid-set, and hand-line systems but, with specific instructions by Keller and Bliesner (1990), can also be applied to center-pivots and linearmove systems. The figure is not presented here because a user needs to refer to Keller and Bliesner (1990) and Allen et al. (2000) for complete and proper use of the estimation method. In general, and as one would expect, for the same environmental conditions, fine sprays have a higher loss rate than coarse sprays and are more affected by wind.

\section{Rain Gauge Errors}

Some of the sprinkler precipitation rate measurement accuracy challenges may be common to rainfall measurements. Yarris (1978) presented information on rain-gauge errors that he learned from hydraulic engineer Earl L. Neff, who was stationed at the Northern Plains Soil and Water Research Center, Sidney, Mont. Neff "found that rain gauges exposed to the wind catch 5 to $15 \%$ less rain than pit gauges and that errors for individual storms range from 0 to $75 \%$, depending upon the storm's wind velocity. Neff says that the error most often made in a rain gauge reading is the assumption that the reading is completely accurate." A pit gauge refers to a gauge that is mounted in a pit such that the gauge opening is flush with the soil surface thus minimizing wind influence.

R. L. Snyder (personal communication, 2001), a biometeorology specialist with the Univ. of California, Davis LAWR, stated that rain gauges in areas with fog can measure $2 \mathrm{~mm}$ of "rain" from fog. For best accuracy of tipping-bucket gauges, he noted that the bucket size needs to be appropriate for the typical rain 
Table 18. Impact of Water Temperature on Sprinkler Spray Loss As Measured in Field with Electrical Conductivity Change [Derived from Mclean et al. (1994)]

\begin{tabular}{|c|c|c|c|c|c|c|c|c|}
\hline $\begin{array}{l}\text { Irrigation } \\
\text { system }\end{array}$ & $\begin{array}{l}\text { Sprinkler } \\
\text { type }\end{array}$ & $\begin{array}{l}\text { Number of } \\
\text { replicates } \\
\text { evaluated }\end{array}$ & $\begin{array}{c}\text { Average water } \\
\text { temperature } \\
\left({ }^{\circ} \mathrm{C}\right)^{\mathrm{a}}\end{array}$ & $\begin{array}{c}\text { Average air } \\
\text { temperature } \\
\left({ }^{\circ} \mathrm{C}\right)\end{array}$ & $\begin{array}{c}\text { Average dew point } \\
\text { temperature } \\
\left({ }^{\circ} \mathrm{C}\right)\end{array}$ & $\begin{array}{c}\text { Average } \\
\text { relative } \\
\text { humidity } \\
(\%)\end{array}$ & $\begin{array}{l}\text { Average } \\
\text { wind speed } \\
\left(\mathrm{m} / \mathrm{s}^{-1}\right)\end{array}$ & $\begin{array}{l}\text { Average } \\
\text { spray loss } \\
\text { (\%) }\end{array}$ \\
\hline \multirow{2}{*}{$\begin{array}{l}\text { Center } \\
\text { pivot }^{\mathrm{c}}\end{array}$} & \multirow{2}{*}{$\begin{array}{l}\text { Impact } \\
\text { sprinkler }^{\mathrm{d}}\end{array}$} & 4 & 25 & 26.6 & 18.8 & 63 & 4.9 & 2.3 \\
\hline & & 11 & 8 & 20.7 & 14.4 & 69 & 3.1 & 0.4 \\
\hline
\end{tabular}

${ }^{\mathrm{a} H i g h e r ~ t e m p e r a t u r e ~ w a t e r ~ w a s ~ f r o m ~ a ~ r i v e r ~ s o u r c e ~ a n d ~ l o w e r ~ t e m p e r a t u r e ~ s o u r c e ~ w a s ~ f r o m ~ g r o u n d w a t e r . ~}$

${ }^{\mathrm{b}}$ Spray Loss $(\%)=\mathrm{EC}_{C C}-\mathrm{EC}_{S} / \mathrm{EC}_{S} \cdot 100$ where $\mathrm{EC}_{C C}=$ electrical conductivity of water in catch container as measured in micro $\mathrm{mhos} / \mathrm{cm}$; $\mathrm{EC}_{S}$ $=$ electrical conductivity of source water as was measured in micro mhos $/ \mathrm{cm}$.

${ }^{\mathrm{c}}$ Pressure at the center pivot was $275 \mathrm{kPa}$.

${ }^{d}$ The height of the sprinklers above the soil surface or crop canopy was not identified.

events that occur at the measurement location. All of the rain that is in the bucket following a rain event will eventually evaporate and will not be measured.

\section{Water Source Temperature Effect on Spray Loss}

Using the electrical conductivity method, Mclean et al. (1994) in Manitoba, Canada reported spray loss with impact sprinklers on a center pivot for two general water temperatures of about 8 and $23^{\circ} \mathrm{C}$ (Table 18). They stated that the temperature of the irrigation water is an important factor in determining the magnitude of the spray loss, with the higher temperature water resulting in about $2 \%$ more evaporative loss than the lower temperature water. However, other environmental factors may have also contributed to the higher loss for the higher water temperature treatments. For example, the average air temperature and average wind speed were larger, and the average relative humidity was lower for the higher water temperature treatment relative to the lower water temperature treatment.

Thompson (1993a, b) also considered the effect of source water temperature on sprinkler droplet evaporation. In Thompson (1993a), evaporation loss predicted by the droplet evaporationtrajectory model, DPEVAP, was about 1.6 times more (3.1 versus $2 \%$ ) when the water was $30^{\circ} \mathrm{C}$ as opposed to $18^{\circ} \mathrm{C}$ (Table 19 ). This difference was identified as being due to the fact that the energy in the system used to evaporate the spray must heat the cold spray more before evaporation can take place.

\section{Impact of Wet Bulb Temperature on Sprinkler Evaporation}

Kincaid and Longley (1989) noted that for sprinkler droplets from a water source that is warmer or colder than the ambient wet bulb temperature, energy is partitioned between heat transfer and evaporation until the wet bulb temperature is reached, and then, evaporation dominates the energy balance. Thompson (1993b) offered a specific example of the Cupid-DPEVAP simulated energy transfer requirements to warm droplet temperature from an experiment in Lincoln, Neb. (year not indicated). An equivalent of $24 \%$ (11\% from the air, $12 \%$ from the crop canopy, and $1 \%$ from the soil) of the net radiation ( $562 \mathrm{Wm}^{-2}$ at irrigation start) during a solid-set irrigation with impact sprinklers was transferred from the plant-environment system to increase the droplet temperature from $13.5^{\circ} \mathrm{C}$ to a wet bulb temperature that was $5^{\circ} \mathrm{C}$ higher. Kincaid and Longely (1989) stated that accurately accounting for the temperature change in flight can significantly increase the accuracy of sprinkler spray evaporation predictions.

\section{Impact of Droplet Flight Time and Spray Drift on Sprinkler Evaporation}

Thompson (1993b) found that droplet flight time was similar to spray drift as wind speeds varied from 0 to $15 \mathrm{~m} / \mathrm{s}$ (e.g. 1.6 and $1.9 \mathrm{~s}$ flight times, respectively, for a droplet diameter of $1.8 \mathrm{~mm}$ ) and concluded that wind has a marginal affect on the amount of inflight evaporation (Fig. 15). D. C. Kincaid (personal communication, 2000) noted that drift loss depends on the area of interest and the wind conditions. On the edge of a field, drift loss can be substantial in windy conditions but insignificant in the middle of the field. However, the writers note that significant drift may result in a large amount of wet canopy evaporation downwind of the sprinklers. This would not technically be droplet evaporation.

\section{Impact of Droplet Size and Nozzle Height on Sprinkler Evaporation}

Kincaid (1989) presented a method for measuring water droplet evaporation volumetrically. The method suspended a droplet of water in an air stream and the droplet volume change was measured with the microneedle syringe from which the droplet was suspended. For droplet diameters of 0.3 to $1.5 \mathrm{~mm}$, Kincaid and Longely (1989) validated the sprinkler evaporation model presented in their paper against measurements using the microneedle syringe method presented in Kincaid (1989). Comparisons

Table 19. Droplet Evaporation Simulated Impact of Water Temperature on Sprinkler Spray Loss for Hot Dry Conditions [Derived from Thompson et al. (1993a)]

\begin{tabular}{lccccc}
\hline $\begin{array}{l}\text { Simulated } \\
\text { sprinkler }\end{array}$ & $\begin{array}{c}\text { Simulated water } \\
\text { temperature } \\
\left({ }^{\circ} \mathrm{C}\right)\end{array}$ & $\begin{array}{c}\text { Simulated air } \\
\text { temperature } \\
\left({ }^{\circ} \mathrm{C}\right)\end{array}$ & $\begin{array}{c}\text { Simulated } \\
\text { relative } \\
\text { humidity } \\
(\%)\end{array}$ & $\begin{array}{c}\text { Simulated } \\
\text { wind speed }\end{array}$ & $\begin{array}{c}\text { Simulated droplet } \\
\text { flight time } \\
(\mathrm{s})\end{array}$ \\
\hline $\begin{array}{l}\text { Impact } \\
\text { sprinkler }\end{array}$ & 30 & 40 & 10 & Calm & 1.7 \\
\hline
\end{tabular}




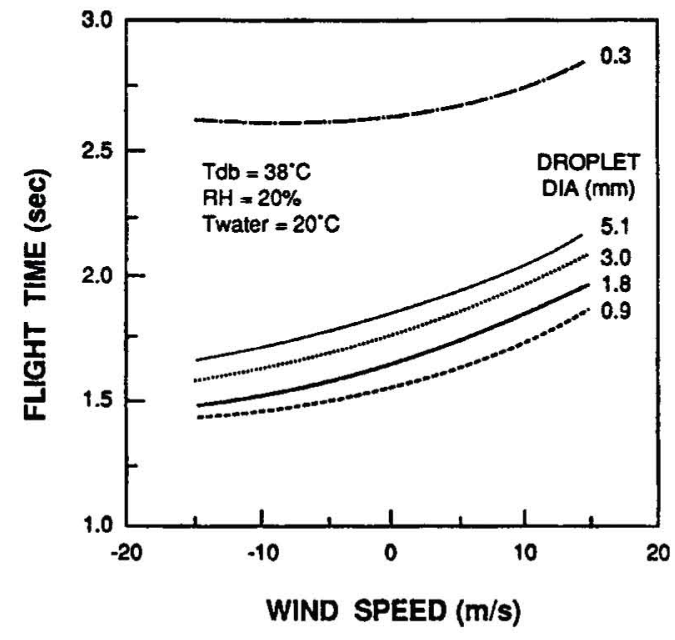

Fig. 15. Droplet Evaporation model prediction of droplet flight time as related to droplet size and wind speed for simulated impact sprinklers operated at $414 \mathrm{kPa}$ with $4.76 \mathrm{~mm}$ nozzles (Thompson 1993b). Reprinted with permission from the American Society of Agricultural Engineers.

of measured and simulated droplet volume loss rate (percentage $\mathrm{s}^{-1}$ ) as a function of droplet size and wind speed for hot and dry air conditions and moderate temperature and moist air conditions are presented in Figs. 16 and 17. As an example, one can consider the impact that different environmental conditions have on a droplet with a diameter of $0.8 \mathrm{~mm}$ where the wind speed is about $3 \mathrm{~m} / \mathrm{s}$. The loss rate for the cool and moist air test was about a quarter of that for the warmer and drier test conditions $(0.25 \% / \mathrm{s}$ versus $1 \% / \mathrm{s}$ ).

Other papers that identified factors influencing droplet size were reported by Mclean et al. (1994) as follows:

Kohl and Wright (1974) and Dadiao and Wallender (1985) showed that sprinkler droplet size was proportional to nozzle diameter. Hills and Gu (1989), Dadiao and Wallender (1985), and Edling (1985) found that the droplet size at any distance from the sprinkler is partially a function of the nozzle size. Kohl and DeBoer (1985)

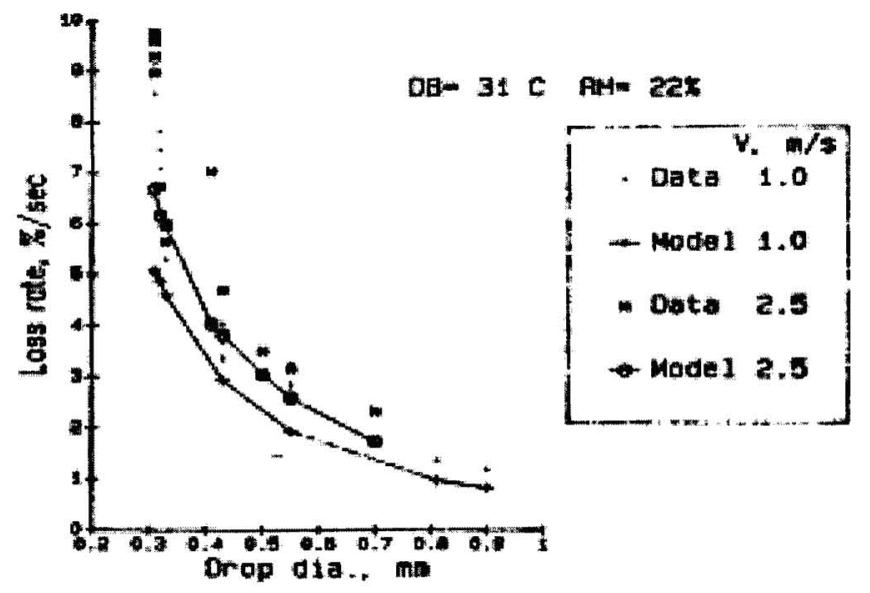

Fig. 16. Rate of droplet volume loss (percentage $\mathrm{s}^{-1}$ ) as related to the initial droplet diameter for hot dry air at two wind velocities (Kincaid and Longely 1989). Reprinted with permission from the American Society of Agricultural Engineers.

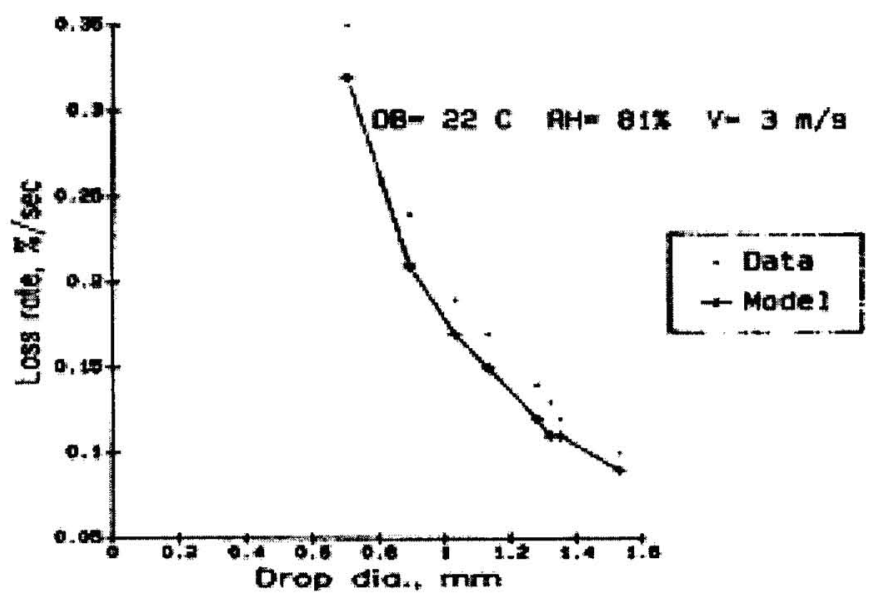

Fig. 17. Rate of droplet volume loss (percentage $\mathrm{s}^{-1}$ ) as related to the initial droplet diameter for moderate temperature and moist air at one wind velocity (Kincaid and Longely 1989). Reprinted with permission from the American Society of Agricultural Engineers.

reported that for low-pressure agricultural sprinklers the geometry of the spray plate surface, rather than the nozzle size and operating pressure, was the dominant parameter that influenced drop size distribution. They also identified that smooth spray plates produce smaller droplets than coarse, grooved plates.

Droplet size distributions for various sprinkler and spray head types are available for evaporation model input (Dadiao and Wallender 1985; Kohl and DeBoer 1985; Solomon et al. 1985; Kincaid et al. 1996).

Thompson (1993b) and Kincaid and Longely (1989) noted that under similar environmental conditions the fraction of the applied volume that is lost to spray evaporation increases as droplet diameter decreases. This applied water fraction loss also increases as nozzle height increases (Thompson 1993b). Fig. 18 presents their example of these relationships from DPEVAP model simulations of impact sprinklers operating at $414 \mathrm{kPa}$ and a nozzle size

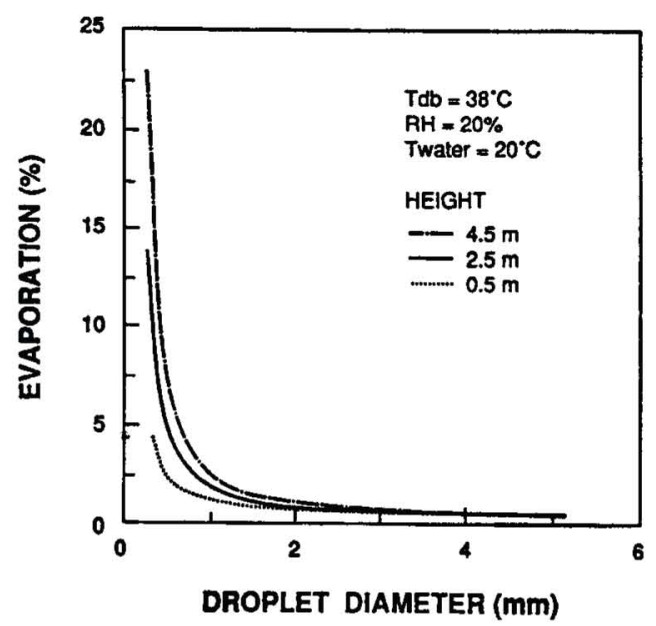

Fig. 18. Droplet Evaporation model prediction of droplet evaporation as related to droplet diameter and nozzle height for a simulated impact sprinkler operated at $414 \mathrm{kPa}$ with $4.76 \mathrm{~mm}$ nozzles (Thompson 1993b). Reprinted with permission from the American Society of Agricultural Engineers. 
of $4.76 \mathrm{~mm}$. For the $4.5 \mathrm{~m}$ nozzle height, the evaporation loss increased from 2.5 to $23.3 \%$ of the application amount when the droplet size decreased from 1 to $0.3 \mathrm{~mm}$. This compares to a loss increase of 1.25 to $4.4 \%$ for the same droplet sizes when the nozzle height is decreased to $0.5 \mathrm{~m}$. Greater nozzle height results in a longer time for evaporation to occur.

Note that total evaporation of sprinkler or spray head droplets as they travel through the air is the sum of the mass loss from the range of the droplet sizes that are produced. The spray losses just listed from Thompson (1993b) are losses for discrete droplet sizes and are not to be confused with total spray losses. That paper partitioned the total applied water over a range of 17 droplet sizes. Papers that identify various sprinkler and spray head droplet size distributions were previously identified.

\section{Conclusion}

The current understanding regarding most aspects of evaporation have been reviewed. Procedures are available to estimate the various components of evaporation, whether they occur from a wet or dry soil surface, wet plant surface, or from sprinkler droplets.

The writers experienced significant challenges in obtaining evaporation data that also included pertinent boundary conditions such as climatic conditions, initial moisture, and soil type, etc. There can also be significant quality control concerns with some evaporation component research. Lysimeter data, in particular, is very sensitive to its site and maintenance conditions.

It is clear from the literature that evaporation is often treated casually in a discussion of ET. But certain irrigation conditions, such as frequent microspray irrigation and rapid cycling of center pivots, can result in a high percentage of soil/plant surface evaporation. For young crops in particular under these conditions, crop coefficient $(K c)$ values are dominated by evaporation rather than by crop physiology.

\section{Appendix. Resources}

\section{Possible Information Sources on Rain Gauge Errors}

- References from the World Meteorological Organization (WMO) were found using the WMO publication search engine: http://www.wmo.ch/web/arep/lib1/catsearch.html (May $25,2001)$.

- The WMO home page is http://www.wmo.ch/index-en.html (May 25, 2001).

- 1973: Annotated bibliography on precipitation measurement instruments, WMO/IHD Projects Report No. 17.A, WMO Contribution to the International Hydrological Decade (IHD), World Meteorological Organization, Geneva, xvii, 278 p. WMO call number: WMO 343.

- 1985: Papers presented at the workshop on the correction of precipitation measurement, Instrument and Observing Methods (IOM) Report No. 25, Zurich, Switzerland, 1-3 April 1985. World Meteorological Organization, Geneva, 288 p. WMO call number: WMO/TD 104.

- 1989: International workshop on precipitation measurements, Instruments and Observing Methods Report No. 48, St-Moritz, Switzerland, 3-7 December 1989. World Meteorological Organization, Geneva, 584 p. WMO call number: WMO/TD 328.

- 1981: R. L. Lampe and J. C. Puzak, "Fourth analysis on reference precipitation samples by the participating World Meteo- rological Organization Laboratories," Environmental Pollution Monitoring Programme No. 7, a contribution to the Global Environmental Monitoring System (GEMS); World Meteorological Organization, Geneva. WMO call number: GAW 7.

- 1983: R. L. Lampe and W. J. Mitchell, "Fifth analysis on reference precipitation samples by the participating World Meteorological Organization Laboratories," Environmental Pollution Monitoring and Research Programme No. 21, a contribution to the Global Environmental Monitoring System (GEMS), World Meteorological Organization, Geneva, 27 p. WMO call number: GAW 21.

- 1967: A. F. Rainbird, "Methods of estimating areal average precipitation," WMO/IHD Projects Report No. 3; in $A W M O$ Contribution to the International Hydrological Decade (IHD), World Meteorological Organization, Geneva xii, 42 p. WMO call number: 551.5:06(100):551.579:551.501.577.

- 1971: J. C. Rodda, "The precipitation measurement paradox: The instrument accuracy problem," WMO/IHD Projects Report No. 16, a WMO Contribution to the International Hydrological Decade (IHD). World Meteorological Organization, Geneva xii, 42 p. WMO call number: WMO 316.

- 1982: B. Sevruk, "Methods of correction for systematic error in point precipitation measurement for operational use," Operational Hydrology Report No. 21, World Meteorological Organization, Geneva xiv, 91 p. ISBN: 92-63-10589-8. WMO call number: WMO 589.

- 1989: B. Sevruk and S. Klemm, "Catalogue of national standard precipitation gauges, instruments and observing methods (IOM)," Report No. 39, World Meteorological Organization, Geneva, 50 p. WMO call number: WMO/TD 313.

\section{Other Rainfall-Related Resources}

Ammani, A., and Lebel, T. (1997). "Langrangian kriging for the estimation of Sahelian rainfall at small time steps." Journal of Hydrology, 192, 125-157.

Amorocho, J. (1982). "Stochastic modeling of precipitation in space and time rainfall fields and catchment response." Statistical analysis of rainfall and runoff, V. P. Singh, ed., Water Resources Publications, Littleton, Colo., 3-20.

Amorocho, J., and Wu, B. (1977). "Mathematical models for the simulation of cyclonic storm sequences and precipitation fields." Journal Hydrol., 32, 329-345.

Hindi, W. N. A., and Kelway, P. S. (1977). "Determination of storm velocities as an aid to the quality control of recording raingauge data." J. Hydrol., 32, 115-137.

Krajewski, W. F., Lakshmi, V., Georgankakos, K. P., and Jain, S. C. (1991). "A Monte Carlo study of rainfall sampling effect on a distribution catchment model." Water Resources Research, 27, 119-128.

Lima, J. L. M. P. de. (1990). "The effect of oblique rain on inclined surfaces: A nomograph for the rain-gauge correction factor." Journal of Hydrology, 115, 4047-412.

Papamichail, D. M., and Metaxa, I. G. (1996). "Geostatistical analysis of spatial variability of rainfall and optimal design of a rain gauge network." Water Resources Management, 10, 107127.

Reich, B. M., and Osborn, H. B. (1982). "Improving point rainfall prediction with experimental watershed data." Statistical analysis of rainfall and runoff, V. P. Singh, ed., Water Resources Publications, Littleton, Colo., 41-54.

Sadler, E. J., and Busscher, W. J. (1989). "High-intensity rainfall rate determination from tipping-bucket rain gauge data." 
Agronomy Journal, 81, 930-934.

Wrage, K. J., Gartner, F. R., and Butler, J. L. (1994). "Inexpensive rain gauges constructed from recyclable 2-liter plastic soft drink bottles." Journal of Range Management, 47, 249-250.

Zawadski, I. I. (1973). "Errors and fluctuations of raingauge estimates of areal rainfall." J. Hydrol., 18, 243-255.

\section{References}

"1998 annual irrigation survey." (1999). Irrig. J., January/February, 29. Allen, R. G., Keller, J., and Martin, D. (2000). "Refine and adjust the design parameters." Center pivot design, The Irrigation Association, Falls Church, Va., 167-186.

Allen, R. G., Pereira, L. S., Raes, D., and Smith, M. (1998). "Crop evapotranspiration: Guidelines for computing crop water requirements." FAO Irrigation and Drainage Paper No. 56, Rome.

Allen, R. G., and Pruitt, W. (1996). "Evaporation and transpiration." $\mathrm{Hy}$ drology Handbook, 2nd Ed., Manual and Report. No. 28 ASCE Task Committee on Hydrology Handbook, Management Group D, New York, 125-249.

Anderson, M. C., Norman, J. M., Meyers, T. P., and Diak, G. R. (2000). "An analytical model for estimating canopy transpiration and carbon assimilation fluxes based on canopy light-use efficiency." Agric. Forest Meteorol., 101, 265-289.

Bresler, E. (1975). "Trickle-drip irrigation: Principles and application to soil-water management." Dept. of Agronomy, Cornell Univ., Ithaca, N.Y.

Brun, L. J., Enz, J. W., Larsen, J. K., and Fanning, C. (1986). "Springtime evaporation from bare and stubble-covered soil." J. Soil Water Conservat., 41, 120-122.

Burt, C. M., et al. (1997). "Irrigation performance measures: Efficiency and uniformity." J. Irrig. Drain. Eng., 123(6), 423-442.

Burt, C. M. (2000). Training manual for Certified Agricultural Irrigation Specialist Program (CAIS) of The Irrigation Association, Irrigation Training and Research Center, California Polytechnic State Univ., San Luis Obispo, Calif.

Burt, C. M., Mutziger, A., Howes, D. J., and Solomon, K. H. (2002). "Evaporation from irrigated land in California." Rep. R02-001, Irrigation Training and Research Center, California Polytechnic State Univ., San Luis Obispo, Calif. 〈http://www.itrc.org/reports/ reportsindex.html>.

Burt, C. M., and Styles, S. W. (1999). "Drip and micro irrigation for trees, vines, and row crops." Irrigation Training and Research Center, California Polytechnic State Univ., San Luis Obispo, Calif.

Chanzy, A., and Bruckler, L. (1993). "Significance of soil surface moisture with respect to daily bare soil evaporation." Water Resour. Res., $29,1113-1125$.

Clark, R. N., and Finley, W. W. (1975). "Sprinkler evaporation losses in the Southern Plains." ASAE Paper No. 75-2573, American Society of Agricultural Engineers, St. Joseph, Mich.

Dadiao, C., and Wallender, W. W. (1985). "Droplet size distribution and water application with low-pressure sprinklers." Trans. ASAE, 28, $511-516$.

Dasberg, S. (1995). "Drip and spray irrigation of citrus orchards in Israel." Proc., 5th Int. Microirrigation Congress, American Society of Agricultural Engineers, St. Joseph, Mich., 281-287.

Edling, R. L. (1985). "Kinetic energy, evaporation and wind drift of droplets from low-pressure irrigation nozzles." Trans. ASAE, 28, 15431550 .

Evett, S. R., Howell, T. A., and Schneider, A. D. (1995a). "Energy and water balances for surface and subsurface drip irrigated corn." Proc., 5th Int. Microirrigation Congress, American Society of Agricultural Engineers, St. Joseph, Mich, 135-140.

Evett, S. R., Howell, T. A., and Schneider, A. D. (1995b). "Wall material and capping effects on microlysimeter temperatures and evaporation." Soil Sci. Soc. Am. J., 59, 329-336.
Evett, S. R., Howell, T. A., and Schneider, A. D. (2000). "Water and energy balances for surface and subsurface drip irrigated corn." Int. Water Irrig. J., 20, 18-22.

Evett, S. R., and Lascano, R. J. (1993). "ENWATBAL.BAS: A mechanistic evapotranspiration model written in compiled BASIC." Agron. J., $85,763-772$.

Farahani, H. J., and Bausch, W. C. (1995). "Performance of evapotranspiration models for maize-bare soil to closed canopy." Trans. ASAE, 38, 1049-1059.

Gallardo, M., Snyder, R. L., Schulbach, K., and Jackson, L. E. (1996). "Crop growth and water use model for lettuce." J. Irrig. Drain. Eng., 122(6), 354-359.

George, T. J. (1955). "Evaporation from irrigation sprinkler sprays as determined by an electrical conductivity method." Masters thesis, Univ. of California.

Hares, M. A., and Novak, M. D. (1992). "Simulation of surface energy balance and soil temperature under strip tillage. II. Field test." Soil Sci. Soc. Am. J., 56, 22-29.

Hermsmeir, L. F. (1973). "Evaporation during sprinkler application in a desert climate." ASAE Paper No. 73-216, American Society of Agricultural Engineers, St. Joseph, Mich.

Hills, D. J., and Gu, Y. P. (1989). "Sprinkler volume mean diameter as a function of pressure." Trans. ASAE, 32, 471-476.

Howell, T. A., Schneider, A. D., and Tolk, J. A. (1991). "Sprinkler evaporation losses and efficiency." Proc., 1991 Central Plains Irrigation Short Course and Equipment Exposition, North Platte, Neb.

Howell, T. A., Steiner, J. L., Schneider, A. D., and Evett, S. R. (1995). "Evapotranspiration of irrigated winter wheat-Southern Plains." Trans. ASAE, 38, 745-759.

Jensen, M. E., Burman, R. D., and Allen, R. G. (1990). Evapotranspiration and irrigation water requirements, ASCE Manual and Report No. 70, New York.

Jensen, M. E., and Haise, H. R. (1963). "Estimating evapotranspiration from solar radiation." J. Irrig. Drain. Div., 89(4), 15-41.

Keller, J., and Bliesner, R. (1990). Sprinkle and trickle irrigation, Van Nostrand Reinhold, New York.

Kincaid, D. C. (1989). "Volumetric water drop evaporation measurement." Trans. ASAE, 32, 925-927.

Kincaid, D. C., and Longley, T. S. (1989). "A water droplet evaporation and temperature model." Trans. ASAE, 32, 457-463.

Kincaid, D. C., Solomon, K. H., and Oliphant, J. C. (1996). "Drop size distributions for irrigation sprinklers." Trans. ASAE, 39, 839-845.

Kohl, K. D., and DeBoer, D. W. (1985). "Drop size distributions for a low pressure spray type agricultural sprinkler." Trans. ASAE, 27, 18361840.

Kohl, K. D., Kohl, R. A., and DeBoer, D. W. (1987). "Measurement of low pressure sprinkler evaporation loss." Trans. ASAE, 30, 10711074.

Kohl, R. A., and Wright, J. L. (1974). "Air temperature and vapor pressure changes caused by sprinkler irrigation." Agron. J., 66, 85-88.

Lamm, F. R., and Manges, H. L. (2000). "Partitioning of sprinkler irrigation water by a corn canopy." Trans. ASAE, 43, 909-918.

Lascano, R. J., Baumhardt, R. L., Hicks, S. K., and Heilman, J. L. (1994). "Soil and plant water evaporation from strip-tilled control: Measurement and simulation." Agron. J., 86, 987-994.

Lascano, R. J., and van Bavel, C. H. M. (1986). "Simulation and measurement of evaporation from a bare soil." Soil Sci. Soc. Am. J., 50, $1127-1133$.

Lascano, R. J., van Bavel, C. H. M., Hatfield, J. L., and Upchurch, D. R. (1987). "Energy and water balance of a sparse crop: Simulated and measured soil and crop evaporation." Soil Sci. Soc. Am. J., 51, 11131121.

Mclean, R. K., Ranjan, R. S., and Klassen, G. (1994). "Measuring spray evaporation losses from sprinkler irrigation systems." ASAE Paper No. 94-2171, American Society of Agricultural Engineers, St. Joseph, Mich.

McNaughton, K. G. (1981). "Net interception losses during sprinkler irrigation." Agric. Meterol., 24, 11-27. 
Meshkat, M., Warner, R. C., and Workman, S. R. (2000). "Evaporation reduction potential in an undisturbed soil irrigated with surface drip and sand tube irrigation." Trans. ASAE, 43, 79-86.

Norman, J. M. (1982). Biometeorology in integrated pest management, J. Hatfield and I. Thomason, eds., Academic Press, New York, 65-99.

Norman, J. M., and Campbell, G. S. (1983). Application of a plantenvironment model to problems in irrigation: Advances in irrigation, D. Hillel, ed., Academic Press, New York, 155-188.

Norman, J. M., and Campbell, G. S. (1998). An introduction to environmental biophysics, 2nd Ed., Springer, New York.

Parlange, M. B., and Katul, G. G. (1992). "Estimation of the diurnal variation of potential evaporation from a wet bare soil surface." $J$. Hydrol., 132, 71-89.

Penman, H. L. (1948). "Natural evaporation from open water bare soil and grass." Proc. R. Soc. London, Ser. A, 193, 120-145.

Priestley, C. H. B., and Taylor, R. J. (1972). "On the assessment of surface heat flux and evaporation using large scale parameters." Mon. Weather Rev., 100, 81-92.

Prihar, S. S., Jalota, S. K., and Steiner, J. L. (1996). "Residue management for reducing evaporation in relation to soil type and evaporativity." Soil Use Manage., 12, 150-157.

Qiu, G. Y., Momii, K., Yano, T., and Lascano, R. J. (1999). "Experimental verification of a mechanistic model to partition evapotranspiration into soil water and plant evaporation." Agric. Forest Meteorol., 93, 79-93.

Ritchie, J. T. (1972). "Model for predicting evaporation from a crop with incomplete cover." Water Resour. Res., 8, 1204-1213.

Ritchie, J. T., and Adams, J. E. (1974). "Field measurement of evaporation from soil shrinkage cracks." Soil Sci. Soc. Am. Proc., 38, 131134.

Seginer, I. (1970). "A resistance model of evaporation during sprinkling." Agric. Meterol., 7, 487-497.

Seginer, I. (1971). "Water losses during sprinkling." Trans. ASAE, 14, $656-659,664$.

Shawcroft, R. W., and Gardner, H. R. (1983). "Direct evaporation from soil under a row crop canopy." Agric. Meterol., 28, 229-238.

Seginer, I. (1973). "A note on sprinkler spray evaporation." Agric. Meterol., 11, 307-311.

Snyder, R. L., Bali, K., Ventura, F., and Gomez-MacPherson, H. (2000). "Estimating evaporation from bare or nearly bare soil." J. Irrig. Drain. Eng., 126(6), 399-403.

Solomon, K. H., Kincaid, D. C., and Bezdek, J. C. (1985). "Drop size distributions for irrigation spray nozzles.” Trans. ASAE, 28, 19661974.
Staggenborg, S. A., Lascano, R. J., and Krieg, D. R. (1996). "Determining cotton water use in a semiarid climate with the GOSSYM cotton simulation model." Agron. J., 88, 740-745.

Steiner, J. L., Kanemasu, E. T., and Clark, R. N. (1983). "Spray losses and partitioning of water under a center pivot sprinkler system." Trans. ASAE, 26, 1128-1134.

Stroonsnijder, L. (1987). "Soil evaporation: Test of a practical approach under semi-arid conditions." Neth. J. Agric. Sci., 35, 417-426.

Taylor, S. A., and Ashcroft, G. L. (1972). Physical edaphology-The physics of irrigated and nonirrigated soils, W. Freeman, San Francisco.

Thompson, A. L. (1993a). "A sprinkler water droplet evaporation and plant canopy model. I. Model development." Trans. ASAE, 36, 735741 .

Thompson, A. L. (1993b). "A sprinkler water droplet evaporation and plant canopy model. II. Model application." Trans. ASAE, 36, 743750 .

Thompson, A. L. (1997). "Testing of a water loss distribution model for moving sprinkler systems." Trans. ASAE, 40, 81-88.

Todd, R. W., Klocke, N. L., Hergert, G. W., and Parkhurst, A. M. (1991). "Evaporation from soil influenced by crop-shading, crop residue, and wetting regime." Trans. ASAE, 34, 461-466.

Tolk, J. A., Howell, T. A., Steiner, J. L., Krieg, D. R., and Schneider, A. D. (1995). "Role of transpiration suppression by evaporation of intercepted water in improving irrigation efficiency." Irrig. Sci., 16, 8995.

Westlands Water District. (1993). Water management plan, Fresno, Calif., $\langle\mathrm{ftp}: / /$ westlandswater.org;wmp993.pdf〉 (Feb. 20, 2001).

Wiser, E. H., Jr., van Schilfgaarde, J., and Wilson, T. V. (1961). "Evapotranspiration concepts for evaluating sprinkler irrigation losses." Trans. ASAE, 4, 128-130, 134.

Wilson, T. B., Bland, W. L., and Norman, J. M. (1999). "Measurement and simulation of dew accumulation and drying in a potato canopy." Agric. Forest Meteorol., 93, 111-119.

Yarris, L. C. (1978). "How much rain does a rain gauge gauge?" J. Agric. Res., 27, 13.

Yates, S. R., Gan, J., Ernst, F. F., Mutziger, A. J., and Yates, M. V. (1996). "Methyl bromide emissions from a covered field. I. Experimental conditions and degradation in soil." J. Environ. Qual., 25, 184-192.

Yazar, A. (1984). "Evaporation and drift losses from sprinkler irrigation systems under various operating conditions." Agric. Water Manage., 8, 439-449. 